\title{
Cardioprotective and Metabolomic Profiling of Selected Medicinal Plants against Oxidative Stress
}

\author{
Nadia Afsheen, ${ }^{1}$ Khalil-ur-Rehman (D), ${ }^{1}$ Nazish Jahan, ${ }^{2}$ Misbah Ijaz, ${ }^{3}$ Asad Manzoor, ${ }^{3}$ \\ Khalid Mahmood Khan, ${ }^{1}$ and Saman Hina ${ }^{1}$ \\ ${ }^{1}$ Department of Biochemistry, University of Agriculture, Faisalabad, Pakistan \\ ${ }^{2}$ Department of Chemistry, University of Agriculture, Faisalabad, Pakistan \\ ${ }^{3}$ Department of Clinical Medicine and Surgery, University of Agriculture, Faisalabad, Pakistan
}

Correspondence should be addressed to Khalil-ur-Rehman; khaliluaf@yahoo.com

Received 28 April 2017; Revised 13 July 2017; Accepted 23 August 2017; Published 14 January 2018

Academic Editor: Patricia Morales

Copyright ( 2018 Nadia Afsheen et al. This is an open access article distributed under the Creative Commons Attribution License, which permits unrestricted use, distribution, and reproduction in any medium, provided the original work is properly cited.

\begin{abstract}
In this research work, the antioxidant and metabolomic profiling of seven selected medicinally important herbs including Rauvolfia serpentina, Terminalia arjuna, Coriandrum sativum, Elettaria cardamom, Piper nigrum, Allium sativum, and Crataegus oxyacantha was performed. The in vivo cardioprotective potential of these medicinal plants was evaluated against surgically induced oxidative stress through left anterior descending coronary artery ligation (LADCA) in dogs. The antioxidant profiling of these plants was done through DPPH and DNA protection assay. The C. oxyacantha and T. arjuna showed maximum antioxidant potential, while the E. cardamom showed poor antioxidative strength even at its high concentration. Different concentrations of extracts of the said plants exhibited the protection of plasmid DNA against $\mathrm{H}_{2} \mathrm{O}_{2}$ damage as compared to the plasmid DNA merely treated with $\mathrm{H}_{2} \mathrm{O}_{2}$. The metabolomic profiling through LC-MS analysis of these antioxidants revealed the presence of active secondary metabolites responsible for their antioxidant potential. During in vivo analysis, blood samples of all treatment groups were drawn at different time intervals to analyze the cardiac and hemodynamic parameters. The results depicted that the group pretreated with HC4 significantly sustained the level of CK-MB, SGOT, and LDH as well as hemodynamic parameters near to normal. The histopathological examination also confirmed the cardioprotective potential of HC4. Thus, the HC4 being safe and inexpensive cardioprotective herbal combination could be considered as an alternate of synthetic drugs.
\end{abstract}

\section{Introduction}

Oxidation is a natural phenomenon that leads to the formation of free radicals known as reactive oxygen species (ROS) [1]. Some of the ROS are very important in cell metabolism including intercellular signaling, phagocytosis, and energy production [2]. However, overproduction of ROS during biological processes resulted in extensive pathological alterations like DNA damage and various degenerative disorders. Humans are constantly exposed to natural DNAdamaging agents such as UV light, dietary agents, and endogenously formed free radicals. Damaged DNA accumulates in the brain, muscle, liver, kidney, and in long-lived stem cell, which causes aging, decline in gene expression, and loss of functional capacity [3].
Antioxidants are compounds that slow down or delay the oxidation process by obstructing the initiation of a series of oxidizing reactions [4]. Owing to the presence of antioxidants, medicinal plants have a shielding effect against various diseases, thus emerging as substantial therapeutic agents. Medicinal plants are a time-honored medicine used since the ancient era for treatment of various ailments in human beings [5]. Herbal medicines, in addition to their traditional values, also hold great public and medical interest worldwide as sources of novel lead compounds for drug development. Hence, the medicinal plants will be natural protective strategy and would be freely available with low cost as compared to synthetic drugs [6].

Pakistan is bestowed with a wide range of plant species with unique biodiversity in different climatic zones [7]. These 
medicinal plants have been used in scientific research for various cardiovascular disorder in human beings $[8,9]$. Currently available synthetic cardioprotective drugs exhibit a number of side effects and are out of reach for poor communities. Cardioprotective effects of some medicinal plants, which are safe and inexpensive, have already been explored [10-13]. Therefore, the green products having cardioprotective and antioxidative potential have attracted many researchers towards metabolomic profiling and phytotherapy. The antioxidative strength of medicinal plants is because of the secondary metabolites present in it [11].

An LC-MS-based metabolomic study has become a powerful analytical tool for assessment of various secondary metabolites in herbal medicine [14]. These secondary metabolites have been found to possess a broad range of therapeutic properties, including antioxidant, cardioprotective, and antihypertensive potential [15]. A thorough integration of information from metabolomics is expected to provide solid evidence-based scientific rationales for the development of modern phytomedicines [16]. Therefore, in this research, the antioxidant potential, metabolomic profiling, and in vivo cardioprotective evaluation of Rauvolfia serpentina, Terminalia arjuna, Coriandrum sativum, Elettaria cardamom, Piper nigrum, Allium sativum, and Crataegus oxyacantha was done to get the potent role of these natural antioxidants in health. All these medicinal plants were selected as these plants have already been reported to possess cardiotonic, antioxidant, and antilipidemic potential [4, 17]. Moreover, the previous literature and the knowledge of CAM practitioners also endorsed the cardioprotective effect of these selected parts of the plants.

\section{Materials and Methods}

2.1. Preparation of Herbal Extract. Different parts of the medicinal plant like the roots of $R$. serpentina, bark of $T$. arjuna, seeds of $C$. sativum and E. cardamom, leaves of $P$. nigrum, and fruit of A. sativum, and C. oxyacantha were collected from the Botanical Garden of the University of Agriculture, Faisalabad, Pakistan and from the local herbal market. All the selected parts of the plants were identified by the plant taxonomist in the Department of Botany, University of Agriculture, Faisalabad, Pakistan. These parts of the plants were washed and pulverized to get fine powder. The powdered plants ( $5 \mathrm{~g}$ of each) were macerated in methanol $(50 \mathrm{~mL})$. The macerate was kept in an orbital shaker for four days. The supernatant was decanted and the residue was remacerated with methanol. The pooled supernatants were combined and filtered through Whatman's filter paper number 1 . The rotary evaporator was used to concentrate the filtrate, and subsequently the filtrate was lyophilized [17].

\subsection{Antioxidant Assay}

2.2.1. 1,1-Diphenyl-2-picrylhydrazyl (DPPH) Free Radical Scavenging Assay. The antioxidant potential was determined by using 1,1-diphenyl-2-picrylhydrazyl as a free radical. The methanolic solution of DPPH $(0.1 \mathrm{mM})$ and plant extract of different concentrations $(20,40,60,80$, and $100 \mu \mathrm{g} / \mathrm{mL})$ were mixed in equal volume. The mixtures was left for 30 minutes in the dark, and the absorbance was noted at $517 \mathrm{~nm}$. Ascorbic acid was used as a standard. The percentage DPPH inhibition of plant extract was calculated as follows:

$$
\text { DPPH inhibition }(\%)=\left[\frac{1-A_{1}}{A_{0}}\right] \times 100,
$$

where $A_{1}$ is the absorbance of the sample, and $A_{0}$ is the absorbance of control $[4,18]$.

2.2.2. DNA Protection Assay. The DNA protection assay of extracts of different concentrations $(100,500$, and $1000 \mu \mathrm{g} /$ $\mathrm{mL}$ ) of selected plants was performed by using the pBR322 plasmid DNA. pBR 322 DNA plasmid $(0.5 \mu \mathrm{L})$ was diluted by using $50 \mathrm{mM}$ sodium phosphate buffer ( $\mathrm{pH} 7.4$ ). After dilution, pBR 322 DNA $(3 \mu \mathrm{L})$ was treated with $5 \mu \mathrm{L}$ of selected concentrations of plant extracts. $4 \mu \mathrm{L}$ of $30 \% \mathrm{H}_{2} \mathrm{O}_{2}$ was added to it, and sodium phosphate buffer ( $\mathrm{pH} 7.4$ ) was used to make the volume up to $15 \mu \mathrm{L}$. The difference in migration between the oxidized and native DNA was observed on 1\% agarose by horizontal DNA gel electrophoresis using a wide mini system (Techview, Singapore). $1 \%$ agarose was prepared by dissolving $1 \mathrm{~g}$ agarose in $100 \mathrm{~mL}$ of $1 \mathrm{X} \times \mathrm{TAE}$ buffer and placed in a microwave oven for two minutes. It was cooled and poured in a casting plate. After solidification, the gel was kept in the sodium phosphate buffer and samples were loaded in the wells one by one. The gel was stained with ethidium bromide and documented by Gene NuGenius unit Syngene model (Cambridge, UK). DNA protection was observed from DNA band corresponding to that of native in the presence and absence of various concentrations $(100,500$, and $1000 \mu \mathrm{L})$ of each plant's extract [19].

2.3. Metabolomic Profiling. Metabolomic profiling of all the selected medicinal plants was performed through liquid chromatography-mass spectrometry (LC-MS) analysis.

2.4. Liquid Chromatography-Mass Spectrometry (LC-MS). The selected medicinal plants were analyzed by using liquid chromatography combined with electrospray ionization mass spectrometry (LC-ESI-MS). The plant extracts were filtered through a $0.45 \mu \mathrm{m}$ syringe filter before analysis. Separation was performed on Surveyor plus HPLC System equipped with Surveyor auto (Thermo Scientific, San Jose, CA, USA). The pump was equipped with a Luna Reverse Phase C-18 analytical column $(4.6 \times 150 \mathrm{~mm}, 3.0 \mu \mathrm{m}$ particle size) (Phenomenex, USA). Solvent elution consisted of LCMS grade methanol and acidified water $(0.5 \%$ formic acid $v / v)$ as the mobile phase A and B, respectively. Solvent elution consisted of gradient system which runs at a flow rate of $0.3 \mathrm{~mL} / \mathrm{min}$. The gradient elution was programmed as follows: from $5 \mathrm{~min}$ in $15 \% \mathrm{~A}$ to $20 \mathrm{~min}$ in $25 \% \mathrm{~B}$ and maintained it till the end of the analysis. A 20 minute reequilibration time was used after each analysis. The column was maintained at $25^{\circ} \mathrm{C}$ and the injection volume was $5.0 \mu \mathrm{L}$. The effluent from the HPLC column was directed to an electrospray ionization mass spectrometer (LTQ XL ${ }^{\mathrm{TM}}$ linear ion trap, Thermo Scientific, River Oaks Parkway, USA). 
TABLE 1: Different herbal combinations given to treatment group.

\begin{tabular}{lccccccc}
\hline Groups & R. serpentina & E. cardamom & P. nigrum & A. sativum & T. arjuna & C. oxyacantha & C. sativum \\
\hline Herbal ratio & & & & & & & \\
HC1 & 1 & 0.5 & 1 & 0.5 & - & - & 0.5 \\
HC2 & 1 & 0.5 & 1 & 0.25 & - & 1 & 0.5 \\
HC3 & 1 & 1 & 0.5 & - & 1 & - & 0.5 \\
HC4 & 0.5 & - & - & 0.5 & 1 & 0.5 & 1 \\
\hline
\end{tabular}

Parameters for analysis were set using negative ion mode with spectra acquired over a mass range from 260 to $2000 \mathrm{~m} / \mathrm{z}$. The optimum values of the ESI-MS parameters were spray voltage $+4.0 \mathrm{kV}$, sheath gas and auxiliary gas were 45 , and 5 units/min, respectively, capillary temperature $320^{\circ} \mathrm{C}$, capillary voltage $-20 \mathrm{~V}$, and tube lens $-66.51 \mathrm{~V} . \mathrm{s}$ The accurate mass spectra data of the molecular ions was processed through the Xcalibur software (Thermo Fisher Scientific Inc, Waltham, MA, USA) [20].

2.5. Selection of Animals. The eighteen male stray dogs of 1-2 years were selected as experimental animals and acclimatized for one week under laboratory conditions $\left(27^{\circ} \mathrm{C}\right.$ in $12 \mathrm{hr}$ dark/light cycle). All the animals were housed in the Animal House, Department of Clinical Medicine and Surgery, University of Agriculture, Faisalabad. They were fed with standard feed. The experiment was performed by taking the approval from the institutional ethics review board in the presence of a licensed veterinarian.

2.6. Herbal Combination Therapy. The four different herbal combinations of selected plant extracts were formed as given in Table 1. These herbal combinations were evaluated for their synergistic cardioprotective potential. The dogs were divided into three groups. The first group of dogs was the control group, to which normal diet was fed for 23 days. The second group was the positive control group, in which the dogs were treated with normal diet for 22 days, and after that, the ligation of the left anterior descending coronary artery (LADCA) was performed on the 23rd day. The third group was the treatment group which was further divided into four subgroups. Each subgroup was pretreated with its respective herbal combination (Table 1) for 22 days. On day 23, all the dogs of the treatment group underwent LADCA ligation. After completion of the surgical procedure, the blood samples were taken at various time intervals ( 0 to $48 \mathrm{hr}$ ) to analyze the cardiac markers (CK-MB, SGOT, and $\mathrm{LDH})$. At the end of the experiment, the dogs were anesthetized by Sodium Pentothal and the hearts were excised for histopathological studies.

2.7. Surgical Induction of Myocardial Infarction. The dogs were anesthetized with Sodium Pentothal $(20 \mathrm{mg} / \mathrm{kg})$. Atropine was administered subcutaneously at a dose of $0.1 \mathrm{mg} /$ $\mathrm{kg}$ once before the surgery to keep the heart rate elevated during the surgical procedure and to reduce the bronchotracheal secretions. The body temperature was monitored and maintained at $37^{\circ} \mathrm{C}$. The animals were ventilated with room air from a positive pressure by using compressed air at the rate of 90 stroke/min and tidal volume of $10 \mathrm{~mL} / \mathrm{kg}$. The left jugular vein was cannulated with polyethylene tube for administration of supplemental anesthetic and saline (0.9\%) infusion. The neck was opened and left thoracotomy was performed to open the thoracic cavity. Anatomy of the left anterior descending coronary artery (LADCA) was examined visually and then ligated $4-5 \mathrm{~mm}$ from its origin and the end of this ligature was passed through polyethylene tube to form a snare. The thoracic cavity was covered with saline-soaked gauze to prevent the heart from drying. After completion of the surgical procedure, the heart was returned to its normal position in the thoracic cavity $[21,22]$.

2.8. Estimation of Hemodynamic Variables. The mean arterial pressure (MAP) and heart rate of dogs in all the groups were calculated. The left thoracic cavity was opened by an incision at the fifth intercostal space and the heart was exposed. A sterile metal cannula was introduced in the cavity of the left ventricle from the posterior apical region of the heart for measuring left ventricular dynamics at preset time throughout the surgical procedure [23].

2.9. Biochemical Analysis. The blood sampling was performed at different time intervals $(0,12,24$, and $48 \mathrm{hr})$ during the experimental period. The cardiac biomarkers including creatine kinase-MB (CK-MB), serum glutamic-oxaloacetic transaminase (SGOT), and lactate dehydrogenase (LDH) were analyzed by using "BioMed kits" having patch numbers MBS705376, BGO094144, and LDHK0103016, respectively. All the kits were purchased by "UH Analytics Pakistan."

2.10. Statistical Analysis. The data was statistically analyzed by using two-way ANOVA and Turkey's multiple comparison tests with the help of GraphPad Prism version 7.00, supplied by developer GraphPad software, Inc. [24]. The results have been presented as Mean $\pm \mathrm{SD}$.

\section{Results}

\subsection{Antioxidant Assay}

3.1.1. DPPH Free Radical Scavenging Activity. The DPPH free radical scavenging activity (in terms of \% age inhibition) of $R$. serpentina, T. arjuna, C. sativum, $P$. nigrum, E. cardamom, $A$. sativum, and $C$. oxyacantha at various concentrations $(20,40$, 60, 80, and $100 \mu \mathrm{g} / \mathrm{mL}$ ) was examined (Figure 1). The $T$. arjuna and $A$. sativum showed higher antioxidant potential even at least concentration of $20 \mu \mathrm{g} / \mathrm{mL}$ as compared to the same concentrations of other selected plants. On the other hand, the E. cardamom presented relatively low antioxidant 


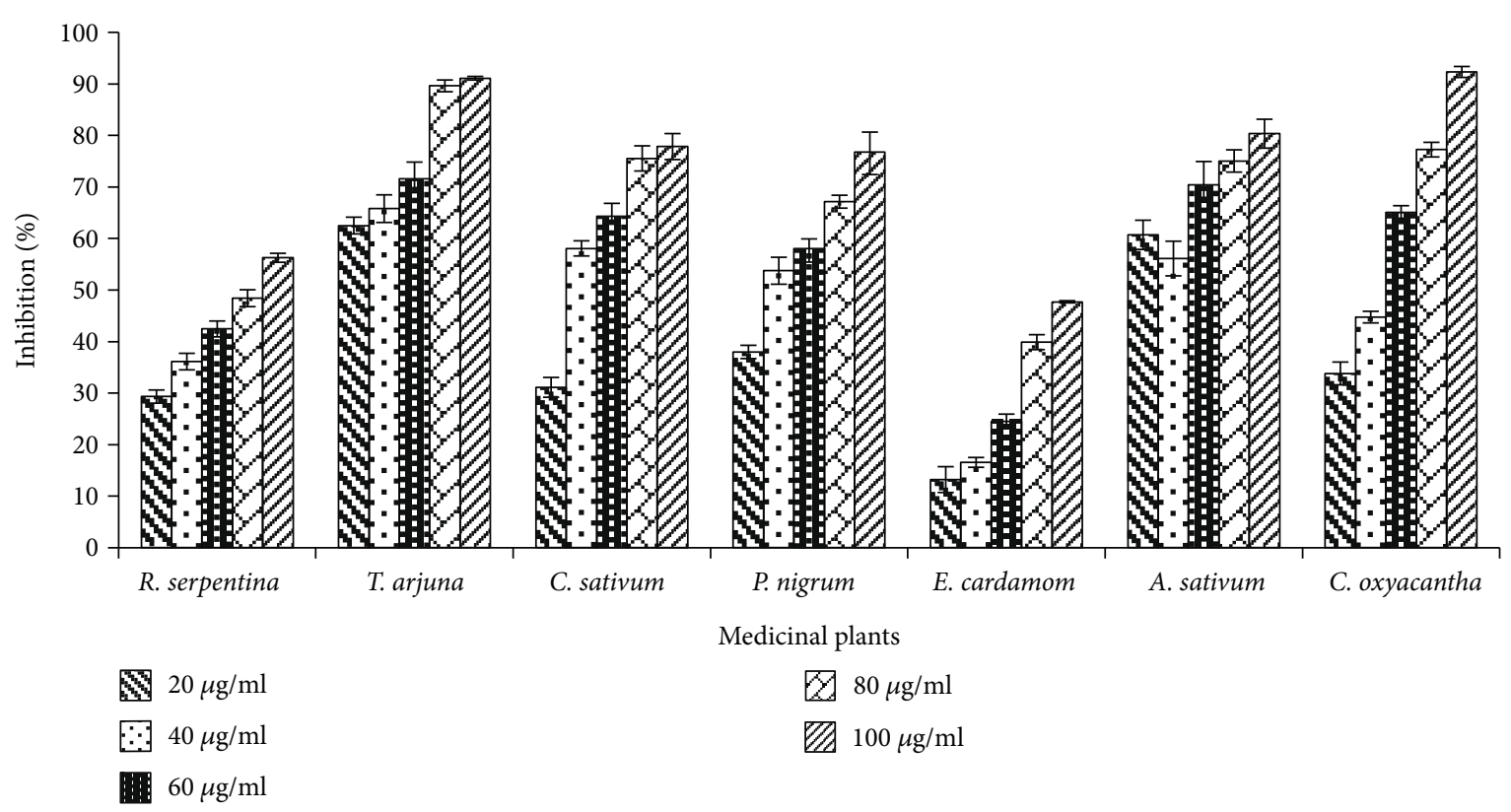

FIGURE 1: Graphical presentation of antioxidant potential of selected medicinal plants through DPPH radical scavenging activity.

potential even at its higher concentration of $100 \mu \mathrm{g} / \mathrm{mL}$. In case of $C$. oxyacantha, the concentration of 20 and $40 \mu \mathrm{g} / \mathrm{mL}$ showed low antioxidative strength but it rapidly increased with further increase in concentration from 60 to $100 \mu \mathrm{g} / \mathrm{mL}$. All the said medicinal plants depicted the dosedependent response for free radical scavenging potential, that is, the activity of plant extracts in terms of $\%$ age inhibition increased with respect to concentrations (Figure 1). The selected medicinal plants could be beneficial to mankind by virtue of their effective antioxidant activity which may able to impart therapeutic role against various diseases.

3.2. DNA Protection Assay. The effect of varying concentrations of medicinal plants on DNA damage along with positive controls $\left(30 \% \mathrm{H}_{2} \mathrm{O}_{2}, 2 \mathrm{mM} \mathrm{FeSO}_{4}\right)$ has been presented in Figures 2 and 3. The free radicals produced in response to $\mathrm{O}_{2}$ and $\mathrm{FeSO}_{4}$ caused the strand cleavage of pBR322 plasmid DNA and resulted in DNA band streaking (Figure 2). All the plants exhibited protection of plasmid DNA against $\mathrm{H}_{2} \mathrm{O}_{2}$ damage as compared to the plasmid DNA merely treated with $\mathrm{H}_{2} \mathrm{O}_{2}$. The DNA protective potential of all concentrations of said medicinal plants was in concentrationdependent manners which revealed that higher concentrations of extracts are more protective against $\mathrm{H}_{2} \mathrm{O}_{2}$-induced damage. The least concentration $(100 \mu \mathrm{g} / \mathrm{mL})$ of $P$. nigrum showed the band streaking (lane 7 of Figure 2) while the concentration of 500 and $1000 \mu \mathrm{g} / \mathrm{mL}$ of $P$. nigrum exhibited a good protection of pBR322 plasmid DNA as presented in the corresponding lanes 8 and 9. However, in case of C. oxyacantha, the concentrations of $100 \mu \mathrm{g} / \mathrm{mL}$ and $500 \mu \mathrm{g} / \mathrm{mL}$ (lanes 4 and 5 of Figure 2) showed noticeable DNA protection. Minor strand breaks were observed with low concentration $(100 \mu \mathrm{g} / \mathrm{mL})$ of $A$. sativum (Figure 2, lane 13), while its higher concentration (500 and $1000 \mu \mathrm{g} / \mathrm{mL}$ ) showed promising protection against DNA damage (Figure 2, lanes 14 and 15).
3.3. Metabolomic Profiling. Metabolomics approaches using LC-MS-based techniques are a useful technique in evaluating the secondary metabolites of medicinal plants. LC-MS-based metabolomics is a powerful new tool for mechanistic studies of drug metabolism.

3.4. Terminalia Arjuna. LC-MS analysis of T. arjuna was performed to evaluate the phytoconstituents including phenolics, flavonoids, and alkaloids. The full mass spectrum obtained by LC-MS analysis was presented in Figure 4. The mass spectrum depicted the high peaks at 413.42, 511.50, $321.33,589.33$, and 685.58. The CIDMS-MS-ESI fragments ion of 685.58 peak resulted in three abundant peaks at $667.50,523.33$, and 457.25. The peak of 667.50 indicated the presence of termiarjunoside 1,3,9,22-tetraol-12-en-28oicacid-3-D-glucopyranoside. The presence of termiarjunoside I from the bark of T. arjuna was also reported in a study by Ali et al. 2006. The fast atom bombardment mass spectroscopy (FABMS) of T. arjuna also displayed a molecular ion peak at $\mathrm{m} / \mathrm{z}=666[\mathrm{M}]^{+}$indicating the presence of termiarjunoside $\mathrm{I}$, with a molecular formula of $\mathrm{C}_{36} \mathrm{H}_{58} \mathrm{O}_{11}$, which was also supported by ${ }^{13} \mathrm{C}$ and distortionless enhancement by polarization transfer (DEPT) NMR spectra. The mass spectrum revealed the highest peak at $301.08,317.25$, and 169.08 which indicate the presence of quercetin, myricetin, and gallic acid in T. arjuna. The presence of gallic acid was further confirmed by MS-MS using CID (30.00). The peak at 125.08 is the consequence of the removal of $\mathrm{COO}^{-}$ from gallic acid. The MS-MS of the peak 317.25 by CID (21.00) showed the highest peaks at 302.08, 241.08, and 179.06. However, the peaks at 193 and 289 may indicate the presence of ferulic acid and catechin, respectively.

3.5. Crataegus oxyacantha. The LC-MS analysis of C. oxyacantha was executed to assess the phytoconstituents. The mass spectrum of C. oxyacantha showed the peak at 593.17 


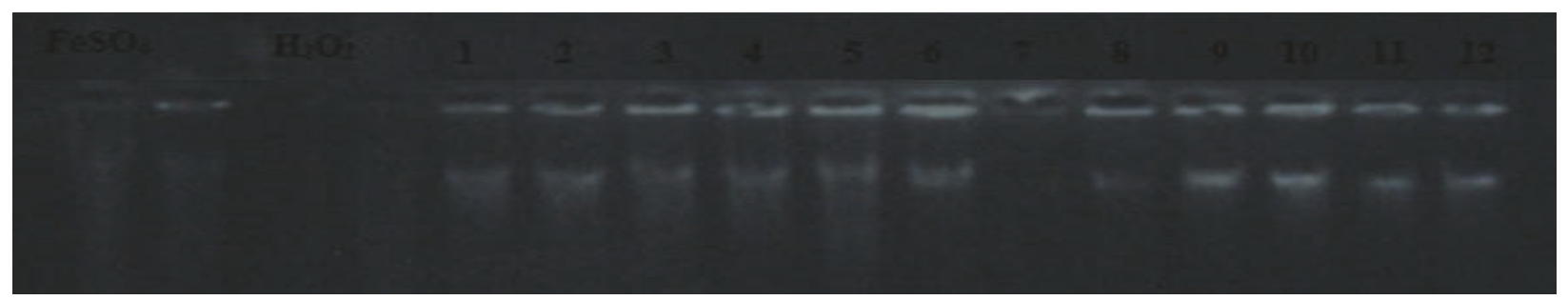

FIGURE 2: Agarose gel electrophoresis pattern of pBR322 plasmid DNA treated with $30 \mathrm{mM} \mathrm{H}_{2} \mathrm{O}_{2}$ in the presence and absence of different plants extract. [lane 1: pBR322 DNA $+30 \mathrm{mM} \mathrm{H}_{2} \mathrm{O}_{2}+\mathrm{P} 1(100 \mu \mathrm{g} / \mathrm{mL})$, lane 2: pBR322 DNA $+30 \mathrm{mM} \mathrm{H}_{2} \mathrm{O}_{2}+\mathrm{P} 1(500 \mu / \mathrm{mL})$, lane 3: pBR322 DNA + $30 \mathrm{mM} \mathrm{H}_{2} \mathrm{O}_{2}+\mathrm{P} 1(1000 \mu \mathrm{g} / \mathrm{mL})$, lane 4: pBR322 DNA + $30 \mathrm{mM} \mathrm{H} \mathrm{O}_{2}+\mathrm{P} 2(100 \mu \mathrm{g} / \mathrm{mL})$, lane 5: pBR322 DNA + $30 \mathrm{mM}$ $\mathrm{H}_{2} \mathrm{O}_{2}+\mathrm{P} 2(500 \mu \mathrm{g} / \mathrm{mL})$, lane 6: pBR322 DNA $+30 \mathrm{mM} \mathrm{H}_{2} \mathrm{O}_{2}+\mathrm{P} 2(1000 \mu \mathrm{g} / \mathrm{mL})$, lane 7: pBR322 DNA $+30 \mathrm{mM} \mathrm{H} \mathrm{O}_{2}+\mathrm{P} 3(100 \mu \mathrm{g} / \mathrm{mL})$, lane 8: pBR322 DNA $+30 \mathrm{mM} \mathrm{H} \mathrm{H}_{2} \mathrm{O}_{2}+\mathrm{P} 3(500 \mu \mathrm{g} / \mathrm{mL})$, lane 9: pBR322 DNA+ $30 \mathrm{mM} \mathrm{H}_{2} \mathrm{O}_{2}+\mathrm{P} 3(1000 \mu \mathrm{g} / \mathrm{mL})$, lane 10: pBR322 $\mathrm{DNA}+30 \mathrm{mM} \mathrm{H} \mathrm{O}_{2}+\mathrm{P} 4(100 \mu \mathrm{g} / \mathrm{mL})$, lane 11: pBR322 DNA $+30 \mathrm{mM} \mathrm{H} \mathrm{O}_{2}+\mathrm{P} 4(500 \mu \mathrm{g} / \mathrm{mL})$, lane $12: \mathrm{pBR} 322 \mathrm{DNA}+30 \mathrm{mM}$ $\left.\mathrm{H}_{2} \mathrm{O}_{2}+\mathrm{P} 4(1000 \mu \mathrm{g} / \mathrm{mL})\right]$.

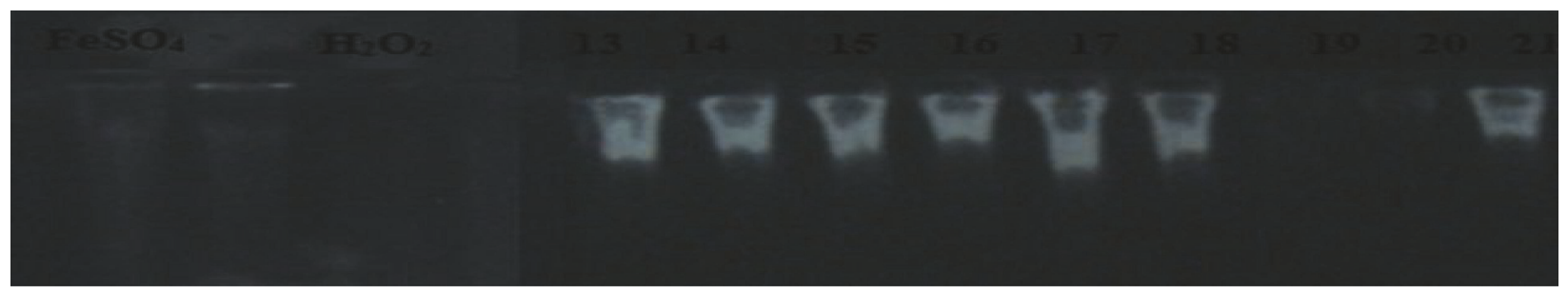

Figure 3: Lane13: pBR322 DNA + $30 \mathrm{mM} \mathrm{H}_{2} \mathrm{O}_{2}+\mathrm{P} 5(100 \mu \mathrm{g} / \mathrm{mL})$, lane 14: pBR322 DNA + $30 \mathrm{mM} \mathrm{H}_{2} \mathrm{O}_{2}+\mathrm{P} 5$ (500 $\left.\mu \mathrm{g} / \mathrm{mL}\right)$, lane 15: pBR322 $\mathrm{DNA}+30 \mathrm{mM} \mathrm{H}_{2} \mathrm{O}_{2}+\mathrm{P} 5(1000 \mu \mathrm{g} / \mathrm{mL})$, lane 16: pBR322 DNA + $30 \mathrm{mM} \mathrm{H}_{2} \mathrm{O}_{2}+\mathrm{P} 6(100 \mu \mathrm{g} / \mathrm{mL})$, lane 17: pBR322 DNA + $30 \mathrm{mM} \mathrm{H} \mathrm{O}_{2}+\mathrm{P} 6$ $(500 \mu \mathrm{g} / \mathrm{mL})$, lane 18: pBR322 DNA $+30 \mathrm{mM} \mathrm{H}_{2} \mathrm{O}_{2}+\mathrm{P} 6(1000 \mu \mathrm{g} / \mathrm{mL})$, lane 19: pBR322 DNA $+30 \mathrm{mM} \mathrm{H} \mathrm{O}_{2}+\mathrm{P} 7(100 \mu \mathrm{g} / \mathrm{mL})$, lane 20 : pBR322 DNA + $30 \mathrm{mM} \mathrm{H} \mathrm{H}_{2} \mathrm{O}_{2}+\mathrm{P} 7(500 \mu \mathrm{g} / \mathrm{mL})$, lane 21: pBR322 DNA $+30 \mathrm{mM} \mathrm{H} \mathrm{O}_{2}+\mathrm{P} 7 \quad(1000 \mu \mathrm{g} / \mathrm{mL})$. P1=T. arjuna; P2=C. oxyacantha; $\mathrm{P} 3=$ P. nigrum; $\mathrm{P} 4=R$. serpentina; $\mathrm{P} 5=$ A. sativum; $\mathrm{P} 6=$ C. sativum; $\mathrm{P} 7=$ E. cardamom.

which indicated the presence of bioactive compounds proanthocynidine with positive mode of ESI (Figure 5). The MS-MS of peak 593 gave the highest peaks at 429.25, 457.17, 411.25, and 401.17, where the peak at 457.17 might indicate the presence of ursolic acid. The LC-MS-ESI also revealed the presence of cratagolic acid at peak of $417(\mathrm{~m} / \mathrm{z})$. The CID MS-MS of the peak 381 of C. oxyacantha showed the peak at 301.17 may give the idea of the presence of quercetin.

3.6. Rauwolfia serpentina. The LC-MS analysis of roots extract of $R$. serpentina was performed. The full mass spectrums along with the highest peaks at 327.25 and 355.33 indicated the presence of ajmaline and yohimbine, respectively (Figure 6). The MS-MS with CID of 25.00 at peak 327 produced different fragment ion peaks. Among these peaks, the peak at $353.25 \mathrm{~m} / \mathrm{z}$ may indicate the presence of ajmailacine. The mass spectrum of $R$. serpentina also depicted the presence of serpentine at the peak 349.52 .

3.7. Allium sativum. A. sativum was subjected to LC-MS analysis to evaluate the presence of phytoconstituents that might be responsible for cardiovascular diseases, dyslipidemia, and hypertension. The LC-MS analysis of A. sativum depicted the highest peaks at 896.92, 917.75, and 782.58 (Figure 7). The MS-MS of 896.92 with CID (25.00) gave the peak at 319.25, which indicated the presence of myricetin. The mass spectrum also showed the presence of apigenin at peak 269.08 with negative mode of ESI.
3.8. Coriandrum sativum. LC-MS analysis of the seed extract of C. sativum was performed to evaluate the active phytoconstituents including phenolics, flavonoids, and alkaloids. The full mass spectrum indicated the existence of caffeic acid at peak 179.08 and isorhamnetin-3-O-glucoside at $478.17 \mathrm{~m} / \mathrm{z}$. The mass spectrum of $C$. sativum also showed apigenin6-C-glucoside at peak $593.25 \mathrm{~m} / \mathrm{z}$ with negative mode of electrospray ionization (Figure 8).

3.9. Elettaria cardamom. The mass spectrum obtained by LC-MS analysis of E. cardamom represented the high peaks at 195.17133.06 and 333.33. The peak at 195.17 indicated the presence of terpinyl acetate. The mass spectrum also depicted the presence of sebinen at 137.08 peak (Figure 9).

3.10. Piper nigrum. The methanolic extract of $P$. nigrum is subjected to LC-MS analysis to determine its bioactive compounds that impart crucial role in cardioprotection. The pippercide, an active ingredient of $P$. nigrum, showed its peak at 219.08 (Figure 10).

\subsection{In Vivo Analysis}

3.11.1. Effect of Herbal Combinations on Cardiac Markers. To investigate whether the combinations of herbal extracts under investigation would offer any added advantage over individual herbal treatment, the effects of HCs were compared with normal and the surgically induced MI group. The potential of herbal combinations was evaluated by analysing the cardiac markers including CK-MB, SGOT, and LDH. 

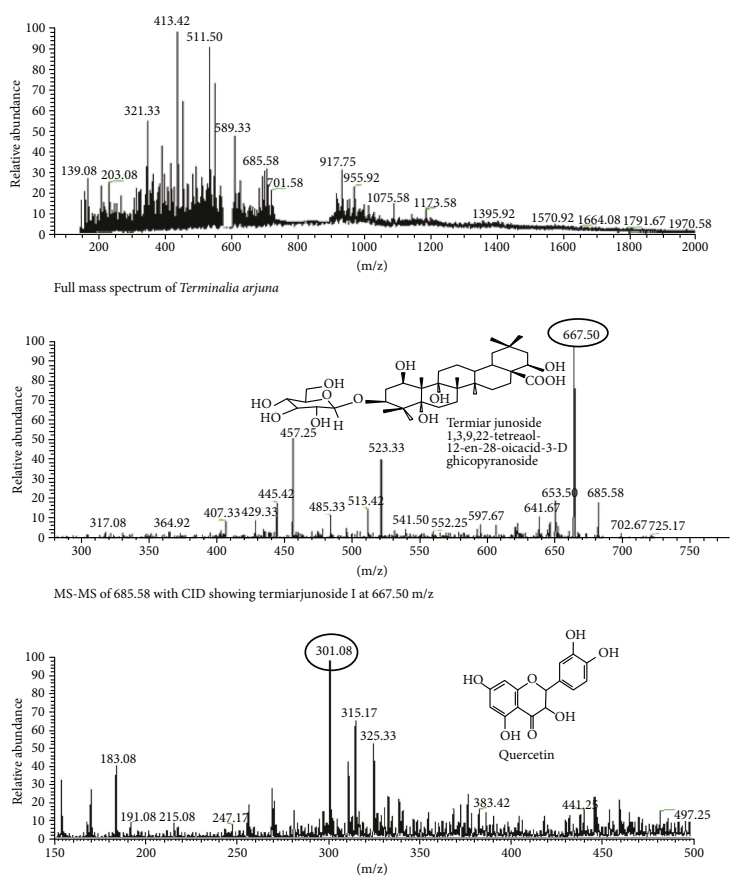

Mass spectrum of T:arjuna showing quercetin at $301.08 \mathrm{~m} / \mathrm{z}$
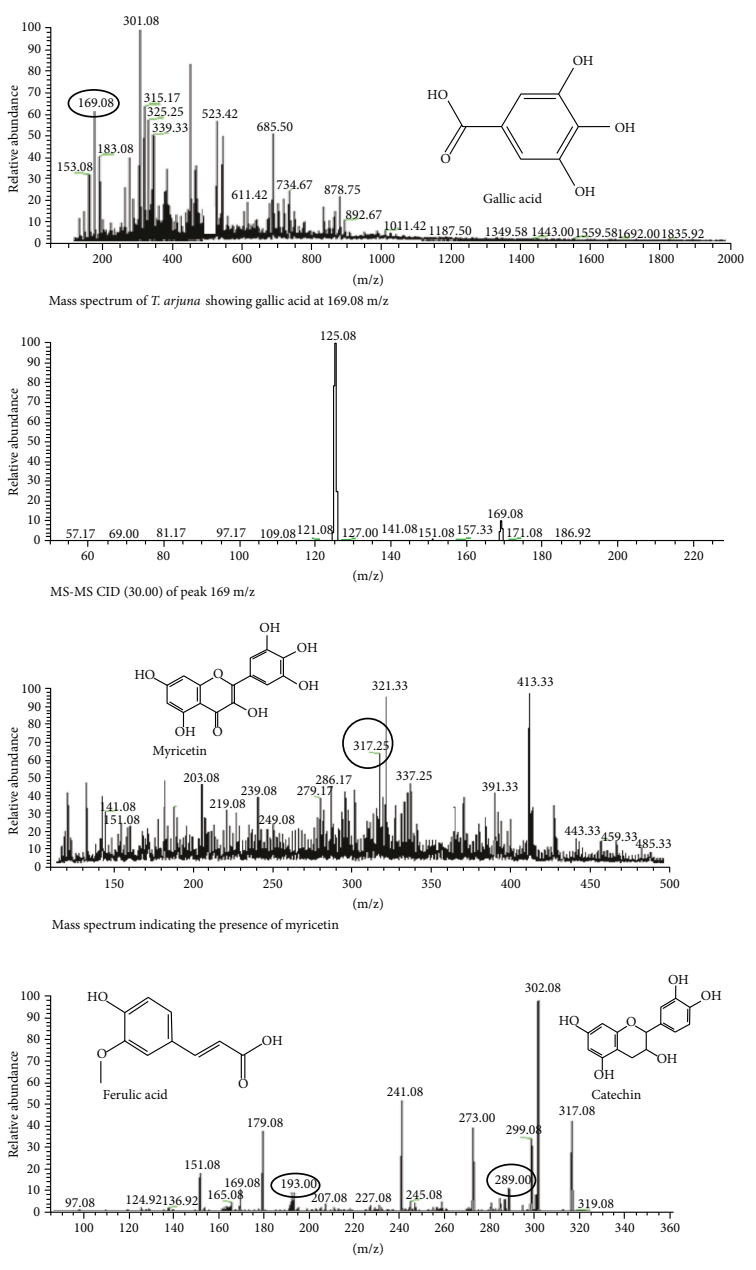

Figure 4: LC-MS analysis of T. arjuna.
The effect of different herbal combinations on CK-MB level against surgically induced MI has been presented in Figure 11(a). The normal control group showed the normal CK-MB level $(173 \pm 3.51 \mathrm{IU} / \mathrm{L})$ throughout the experimental period. There was a considerable increase in the level of CK-MB in the positive control group after $12 \mathrm{hr}$ of left anterior descending coronary artery ligation while the level of enzyme was further raised up to $294.3 \pm 1.53 \mathrm{IU} / \mathrm{L}$ after $24 \mathrm{hr}$. The first herbal combination (HC1) did not significantly $(p>0.05)$ restored the CK-MB level after 12 and $24 \mathrm{hr}$ of ligation as compared to the normal control group. In comparison of $\mathrm{HCl}$, the group pretreated with $\mathrm{HC} 2$ showed better maintenance of CK-MB level after 12 and $24 \mathrm{hr}$ of ligation. A decrease in CK-MB level was observed in group pretreated with $\mathrm{HC} 4$ after $12 \mathrm{hr}$ of ligating left anterior descending coronary artery. After $24 \mathrm{hr}$ of ligation, this group showed considerable decline in the level of CK-MB that was very close to the control group. The prior administration of HC4 depicted the better maintenance of the serum CK-MB as compared to other herbal combinations.

The effect of different herbal combinations on the level of SGOT has been presented in Figure 11(b). In the normal control group, the SGOT level was $43 \pm 2$ and $46 \pm 1.05 \mathrm{IU} / \mathrm{L}$ with time intervals of 12 and $24 \mathrm{hr}$, respectively. The SGOT level was $115 \pm 1.527 \mathrm{IU} / \mathrm{L}$ and $123 \pm 1.154 \mathrm{IU} / \mathrm{L}$ after the corresponding time intervals of 12 and $24 \mathrm{hr}$ of LADCA ligation in the positive control group. The $\mathrm{HCl}$ showed the SGOT level with a value of $94 \pm 1.53 \mathrm{IU} / \mathrm{L}$ after $12 \mathrm{hr}$ and $74 \pm 1 \mathrm{IU} / \mathrm{L}$ after $24 \mathrm{hr}$ of ligation. The pretreatment of HC2 significantly $(p>0.05)$ maintained at the level of SGOT after $24 \mathrm{hr}$ of ligation in LADCA as compared to the positive control group. There was no considerable variation in the outcomes of $\mathrm{HC} 1$ and $\mathrm{HC} 3$ preventive treatment. However, the pretreatment of $\mathrm{HC} 4$ showed maximum potential against myocardial infarction as it upholds the SGOT level $73 \pm 1 \mathrm{IU} / \mathrm{L}$ after $12 \mathrm{hr}$ and $53 \pm 1.53 \mathrm{IU} / \mathrm{L}$ after $24 \mathrm{hr}$ of LADCA ligation.

The preventive treatment of herbal combinations against surgically induced MI on the level of LDH has been presented graphically in Figure 11(c). The serum analysis of the normal control group revealed $223 \pm 1.15$ to $235 \mathrm{IU} / \mathrm{L}$ of $\mathrm{LDH}$ from 0 to $48 \mathrm{hr}$, respectively. The LDH level in the positive control group was considerably higher as compared to the normal control group. The group of dogs pretreated with $\mathrm{HC1}$ showed $382.33 \pm 1.53 \mathrm{IU} / \mathrm{L}$ of $\mathrm{LDH}$ after $12 \mathrm{hr}$ and $283 \pm$ $1.15 \mathrm{IU} / \mathrm{L}$ after $24 \mathrm{hr}$ of ligation. In dogs treated with HC2, the LDH level was $291.67 \pm 1.15 \mathrm{IU} / \mathrm{L}$ and $264 \pm 2.08 \mathrm{IU} / \mathrm{L}$ at corresponding time intervals of 12 and $24 \mathrm{hr}$ after LADCA ligation. While the pretreatment of HC3 showed $343 \pm$ $1.53 \mathrm{IU} / \mathrm{L}$ level of LDH after $12 \mathrm{hr}$ and maintained at the level of $250 \pm 1 \mathrm{IU} / \mathrm{L}$ after $24 \mathrm{hr}$ of ligation. The preventive treatment of $\mathrm{HC} 4$ revealed significant maintenance of $\mathrm{LDH}$ level after $12 \mathrm{hr}$ of ligation (Figure 11(c)).

The HC4 showed the prominent cardioprotective potential by maintaining the cardio-specific markers near the normal against surgically induced myocardial infarction after $24 \mathrm{hr}$ of LADCA ligation. Although the precise mechanism of the cardioprotective potential of HCs in surgically 

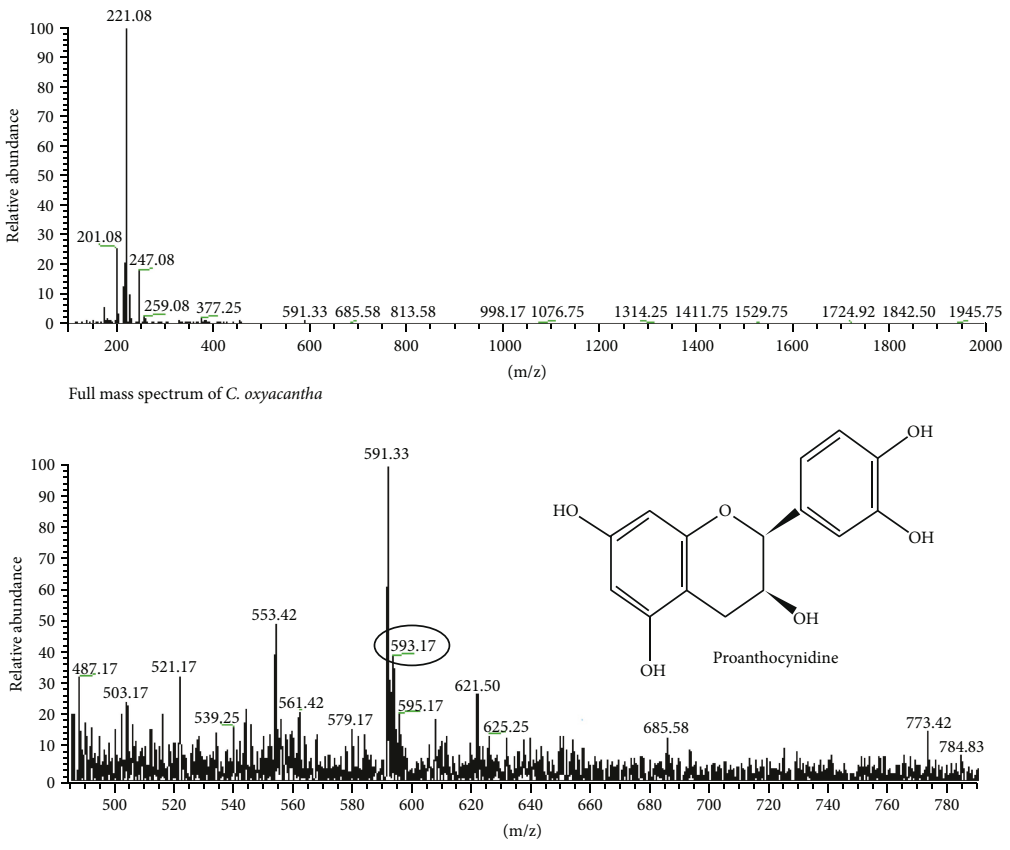

Mass spectrum of C. oxyacantha showing proanthocynidine $593.17 \mathrm{~m} / \mathrm{z}$

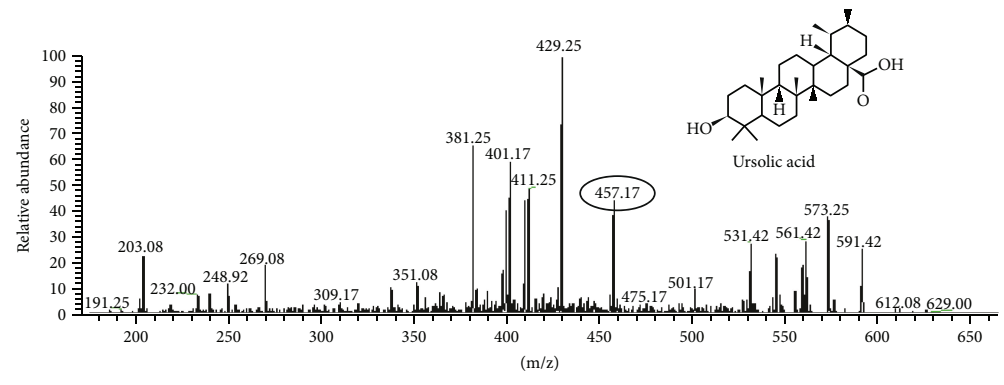

MS-MS with CID (20.00) of peak 591.42 showing ursolic acid at $457.25 \mathrm{~m} / \mathrm{z}$

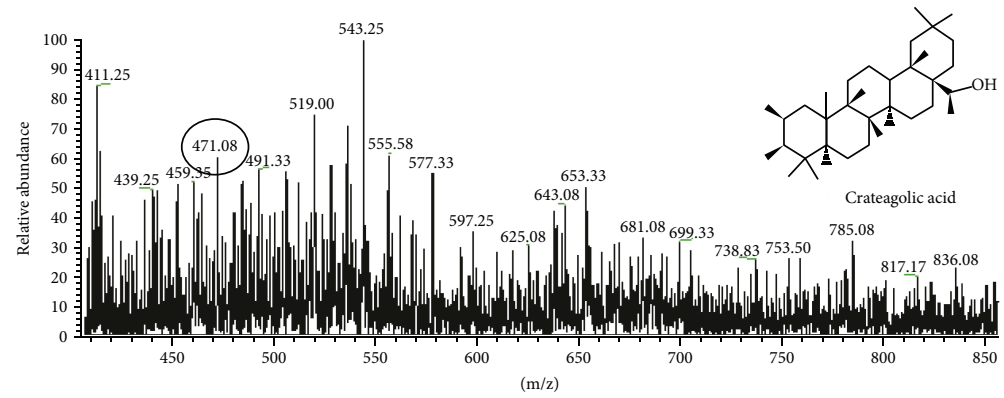

Mass spectrum of C. oxyacantha showing crateagolic acid at $471.08 \mathrm{~m} / \mathrm{z}$

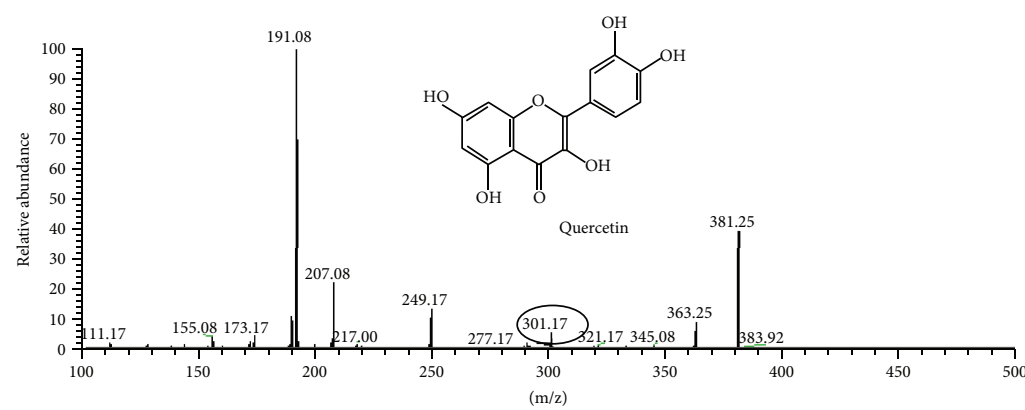

MS-MS of 381 of C. oxyacantha with CID (20.00) showing quercetin at $301.17 \mathrm{~m} / \mathrm{z}$

FIGURE 5: LC-MS analysis of C. oxyacantha. 


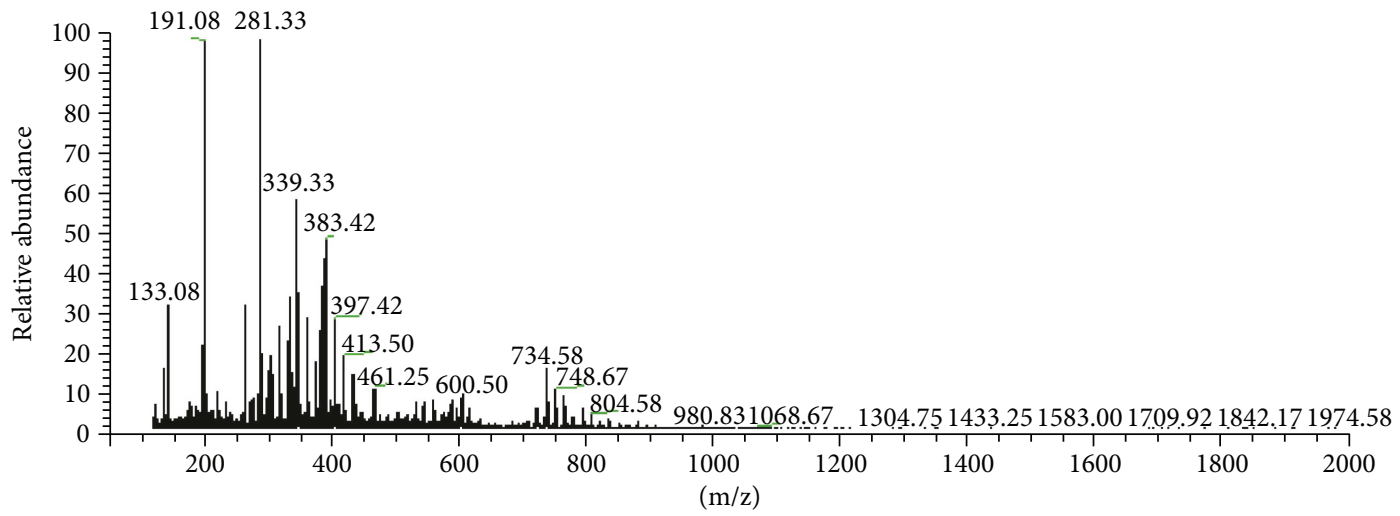

Full mass spectrum of R. serpentina

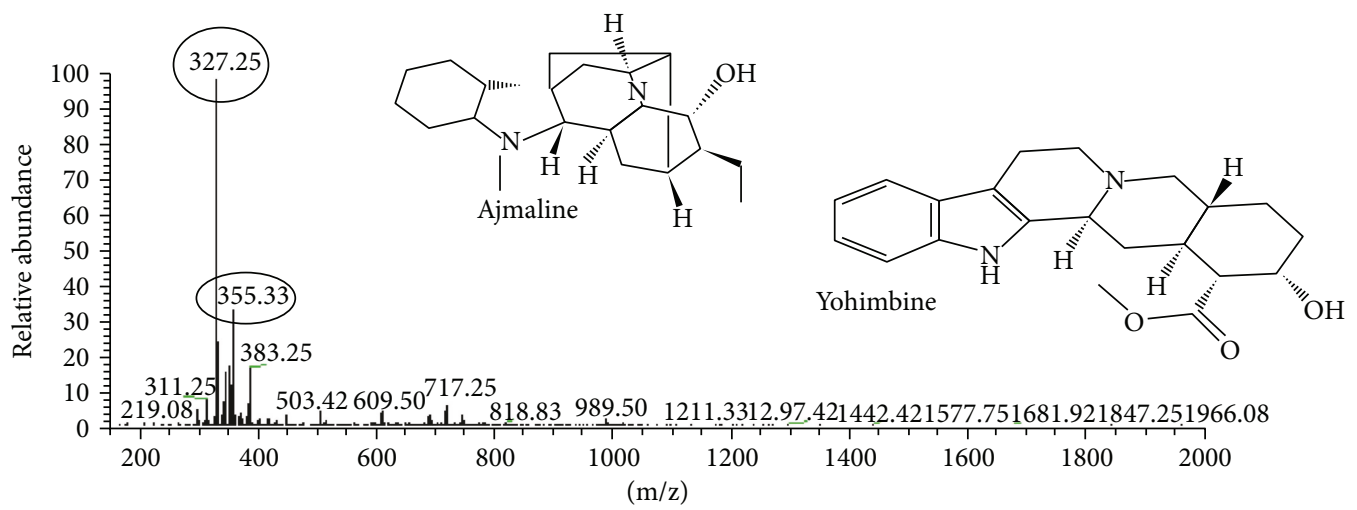

Mass spectrum of R. serpentina showing yohimbine at 355.33 and ajmaline at $327.25 \mathrm{~m} / \mathrm{z}$

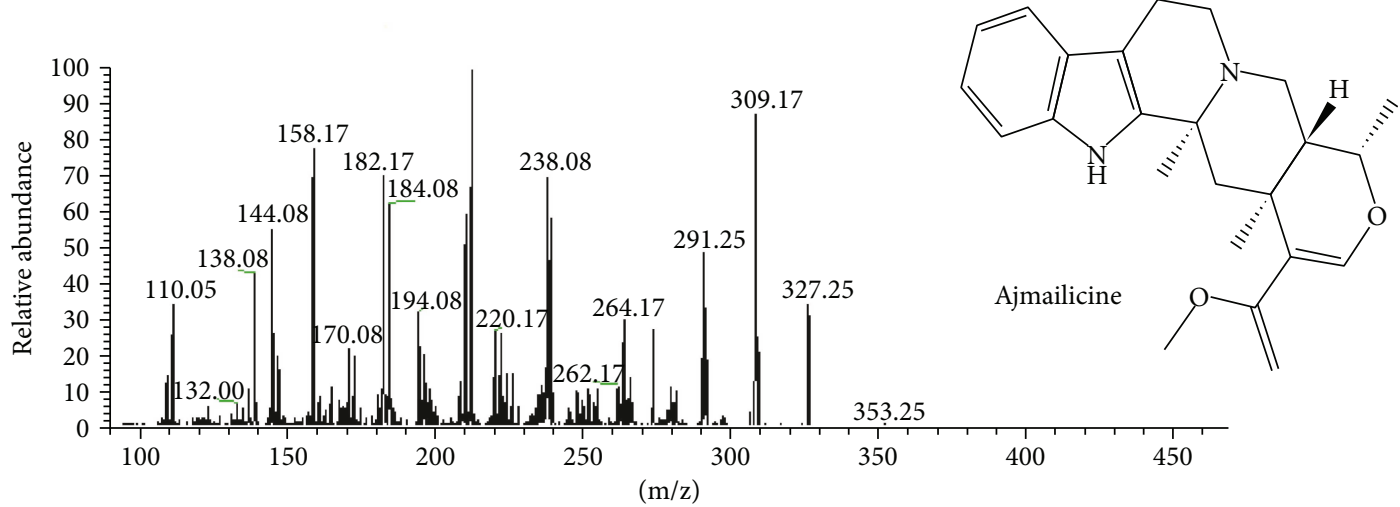

MS2 of peak 327 with CID (25.00) showing ajmailicine at $353.25 \mathrm{~m} / \mathrm{z}$

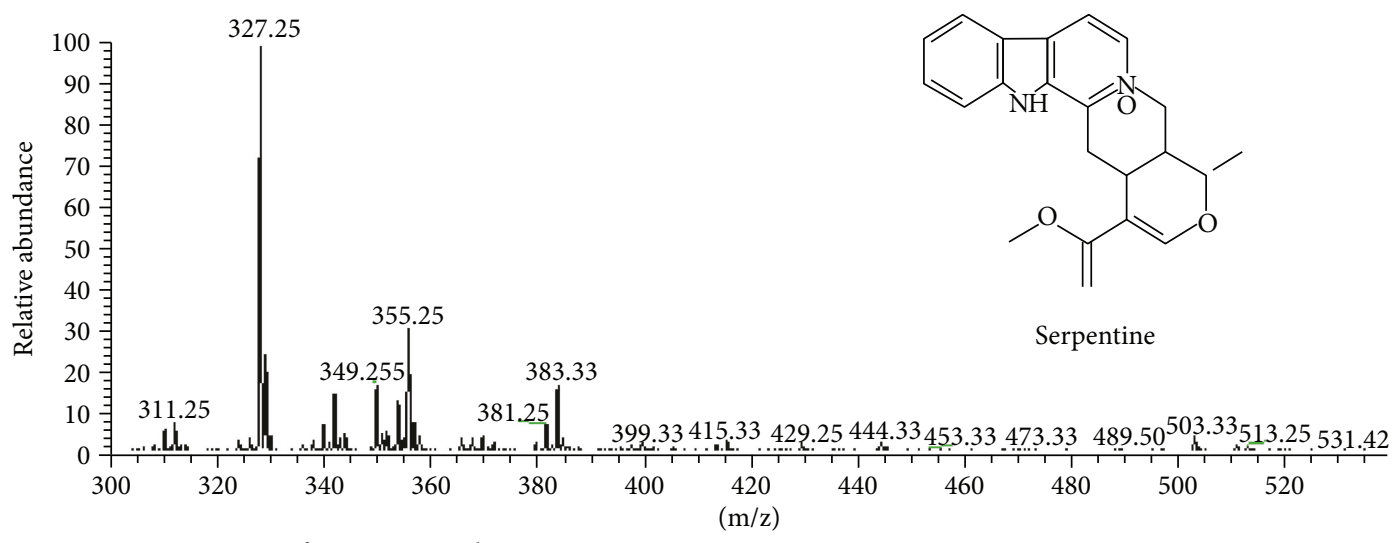

Mass spectrum of R. serpentina showing serpentine at $349.25 \mathrm{~m} / \mathrm{z}$

FIgURE 6: LC-MS analysis of R. serpentina. 


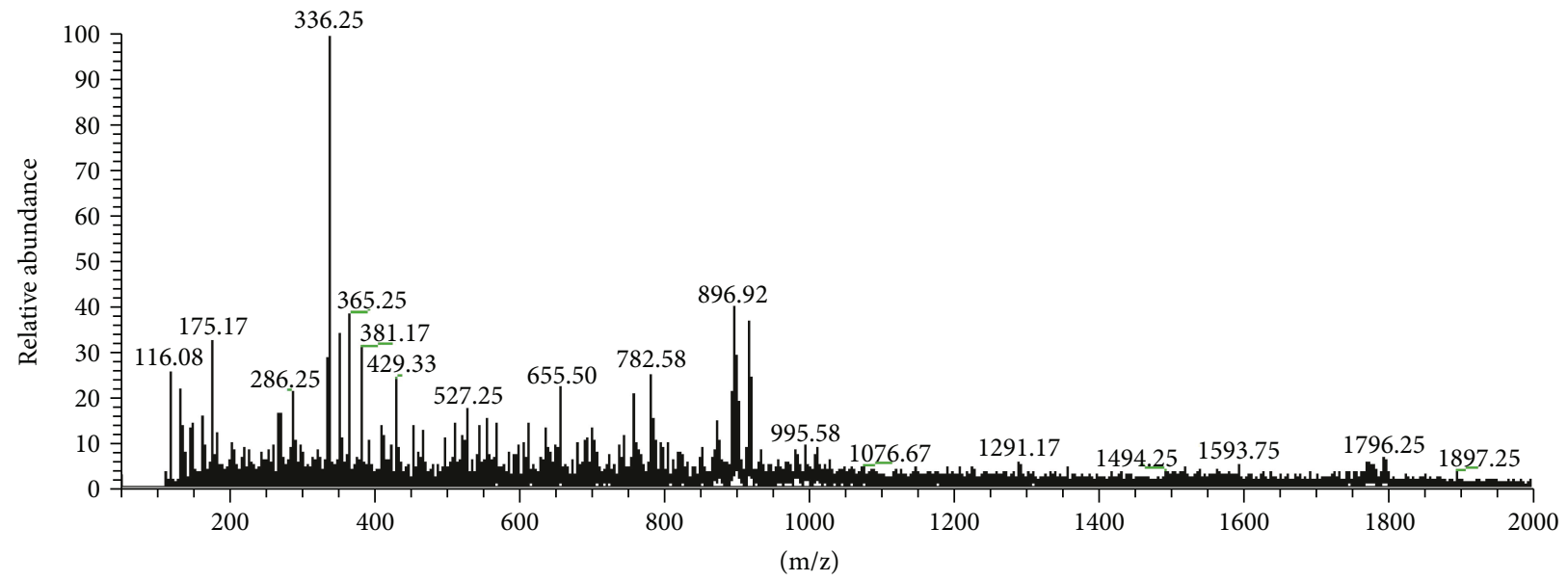

Full mass spectrum of A. sativum

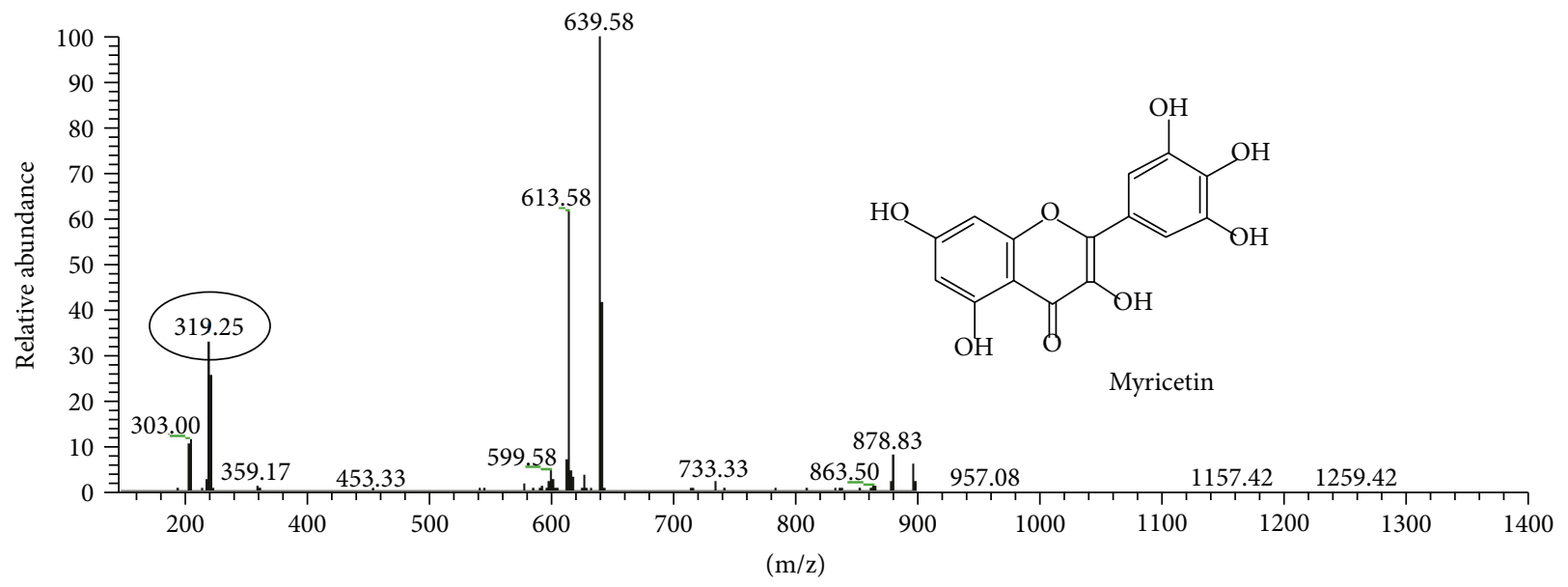

MS $^{2}$ CID 25.00 of 896 of A. sativum showing myricetin at $319.25 \mathrm{~m} / \mathrm{z}$

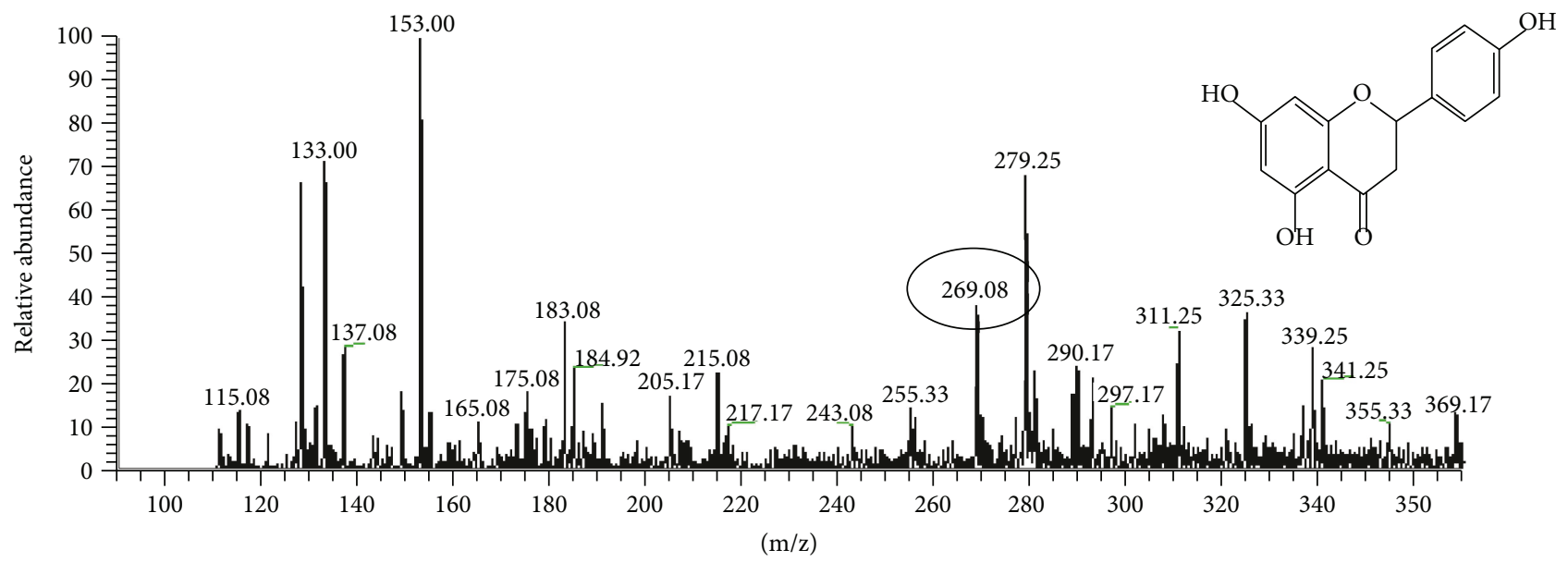

Mass spectrum of A. sativum apigenin at $327.25 \mathrm{~m} / \mathrm{z}$

FIGURE 7: LC-MS analysis of A. sativum.

induced myocardial injury is not fully understood, it may be attributed to its favorable myocardial adaptogenic properties. Furthermore, this herbal combination might have the potential for the management of patients at risk of myocardial infarction.

\subsection{Effect of Herbal Combinations on Hemodynamic Variable}

3.12.1. The Mean Arterial Pressure. Measurement of the hemodynamic variables was also incorporated into the experimental design for better understanding and more precise 


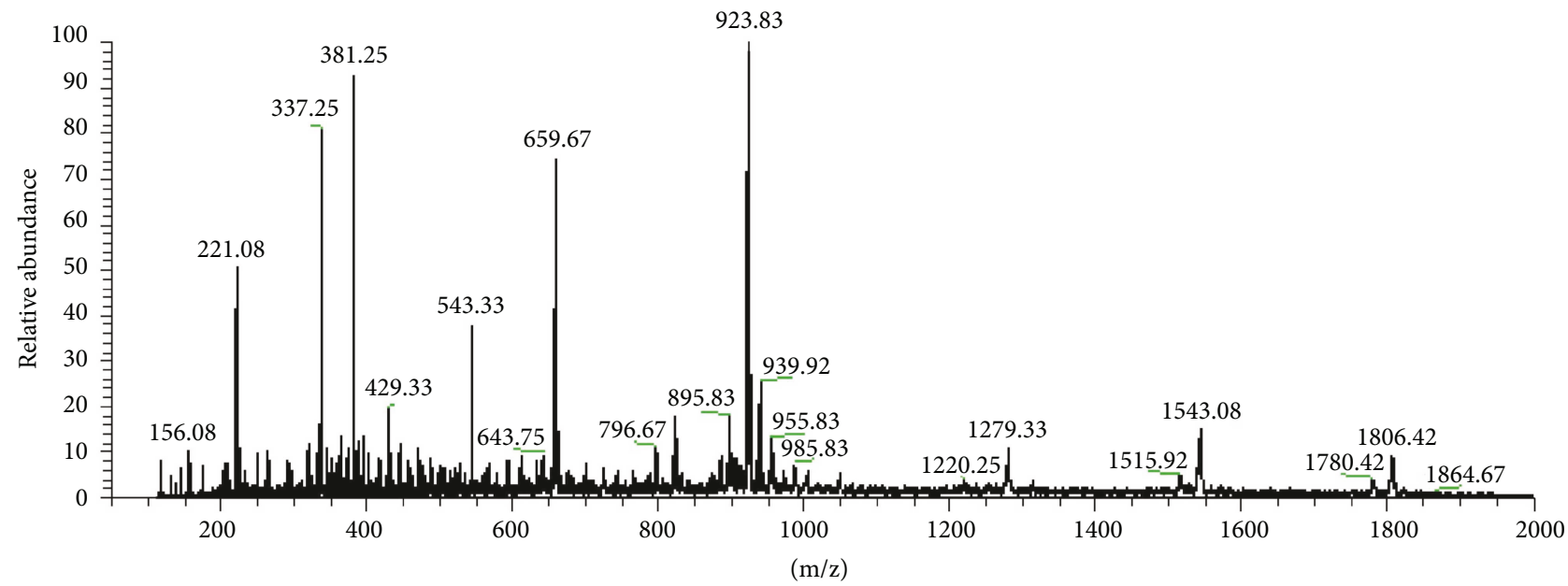

Full mass spectrum of C. sativum

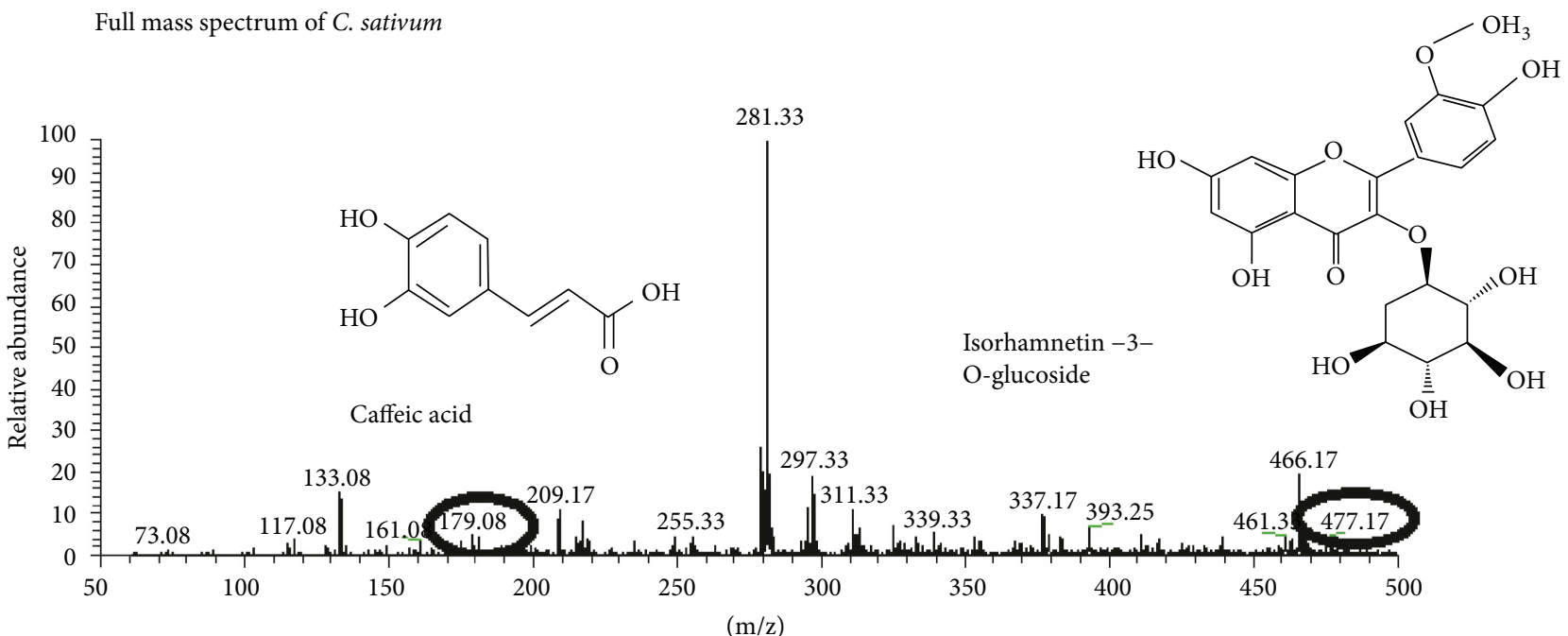

Mass spectrum of C. sativum showing caffeic acid at $179.08 \mathrm{~m} / \mathrm{z}$ and isorhamnetin-3-O-glucoside at $477.17 \mathrm{~m} / \mathrm{z}$

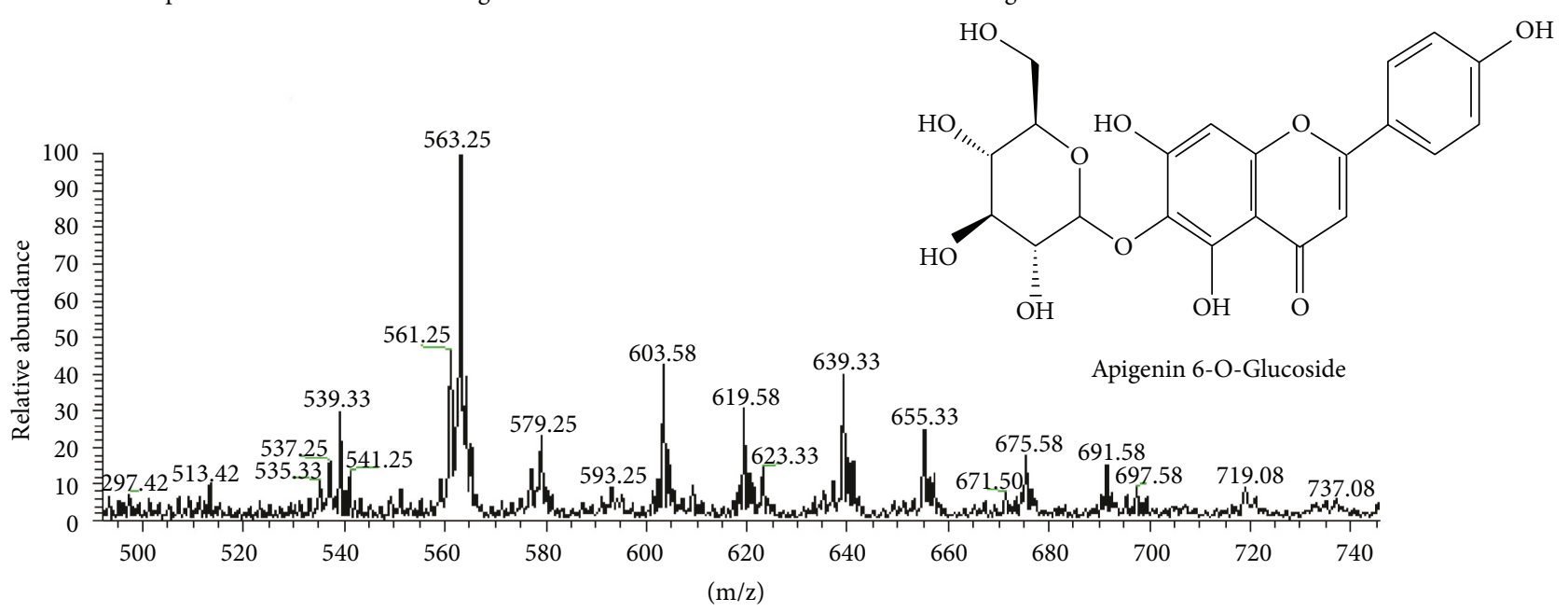

Mass spectrum of Coriandrum sativum showing apigenin-6-C-glucoside at $593.25 \mathrm{~m} / \mathrm{z}$

FIGURE 8: LC-MS analysis of C. sativum.

information of the correlation between biochemical and functional changes in the myocardium subjected to surgically induced damage. The normal control group depicted the $85 \pm 6.81$ mean arterial pressure (MAP) $\mathrm{mmHg}$ while the positive control group showed the decline in MAP (33 \pm $4.35 \mathrm{mmHg}$ ) after occlusion in LADCA (Figure 12). The pretreatment of $\mathrm{HC} 1$ tried to sustain the level of MAP up to $52 \pm 5.13 \mathrm{mmHg}$. However, the group treated with HC2 and 


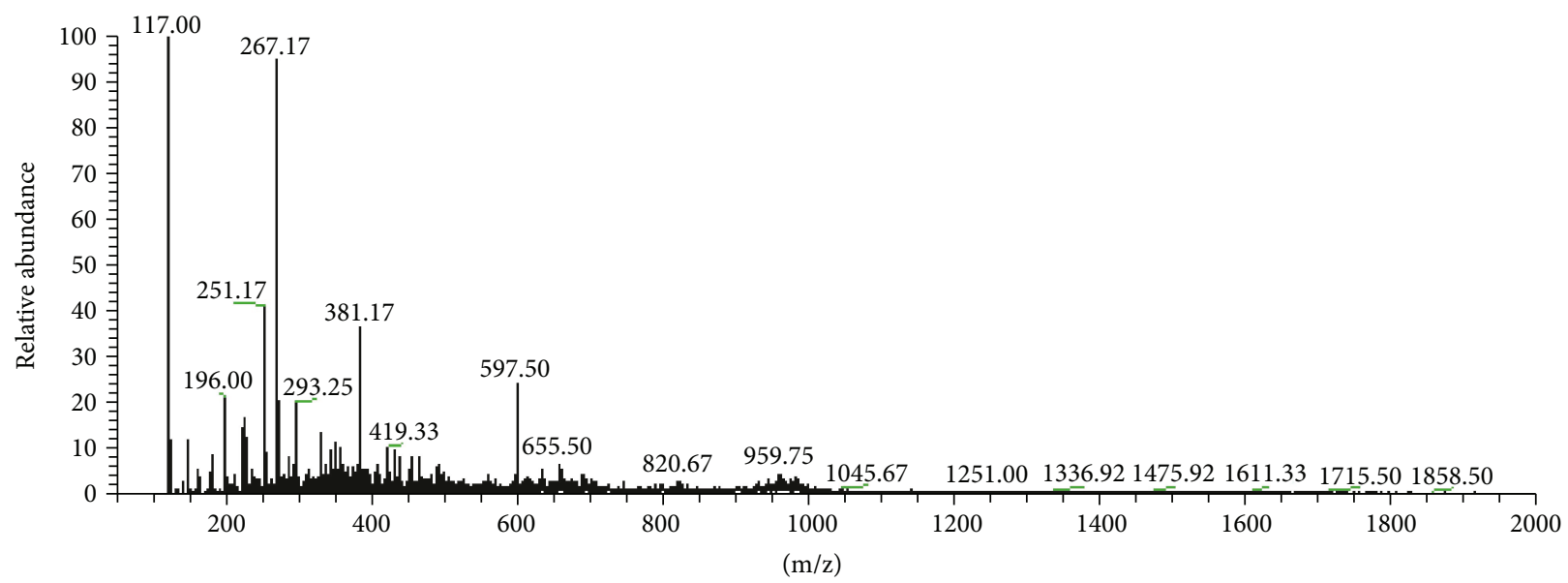

Full mass spectrum of E. cardamom

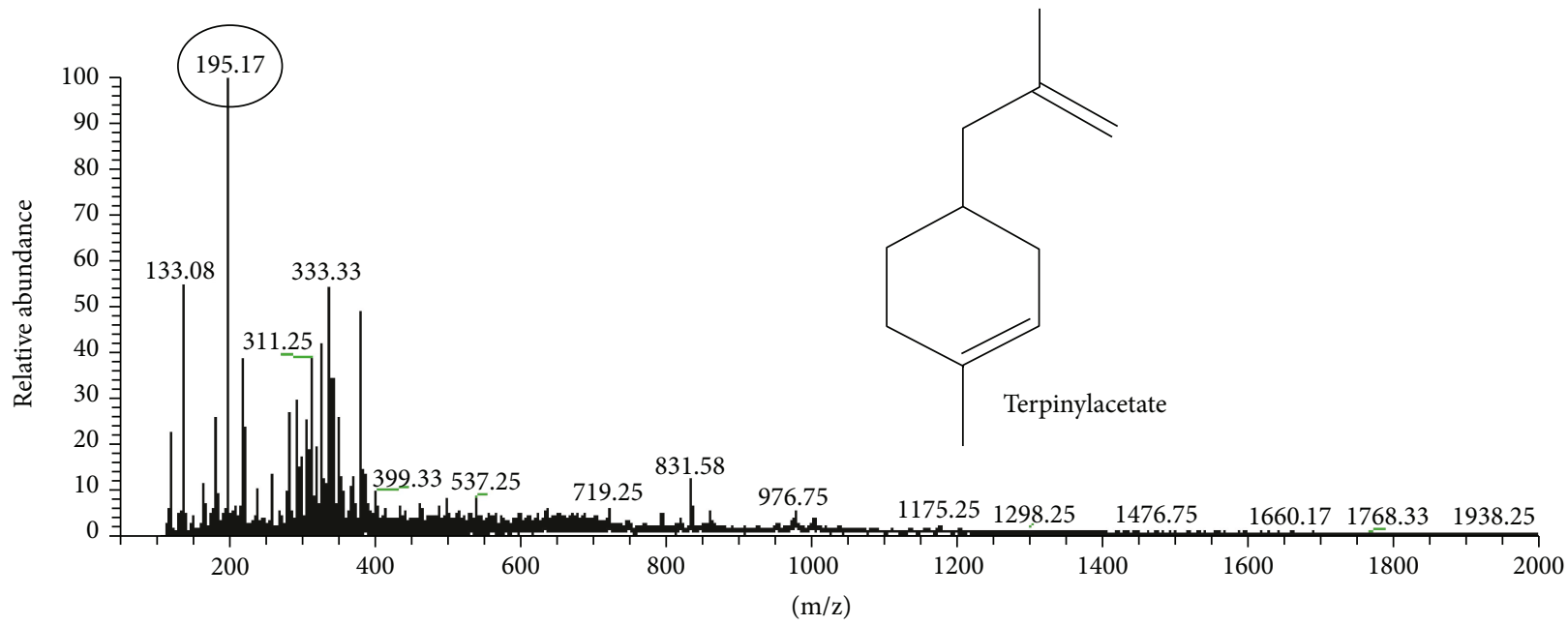

Mass spectrum of E. cardamom showing terpinylacetate at $195.17 \mathrm{~m} / \mathrm{z}$

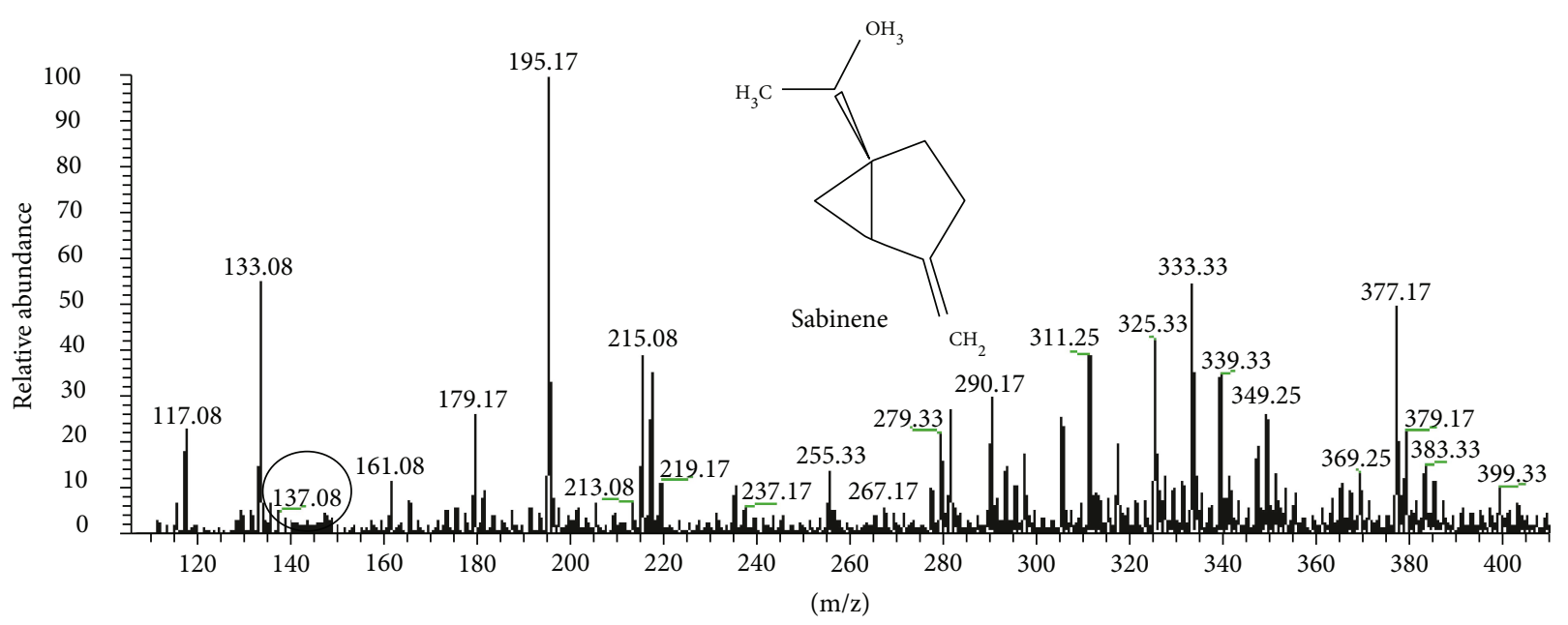

Mass spectrum of E. cardamom showing sabinene at $137.08 \mathrm{~m} / \mathrm{z}$

FIgURE 9: LC-MS analysis of E. cardamom.

HC4 substantially maintained the MAP $76 \pm 4.04 \mathrm{mmHg}$ and $77 \pm 5.13 \mathrm{mmHg}$, respectively, as compared to other groups.

Similarly, in the positive control group, there was an abrupt increase in heart rate (HR) beats/min $(277 \pm 8.02)$ as compared to the normal control group ( $186 \pm 4.04$ beats/ min). On the other hand, the pretreatment of surgically induced MI groups with herbal combinations revealed significant $(p>0.05)$ maintenance of $\mathrm{HR}$ as compared to the 


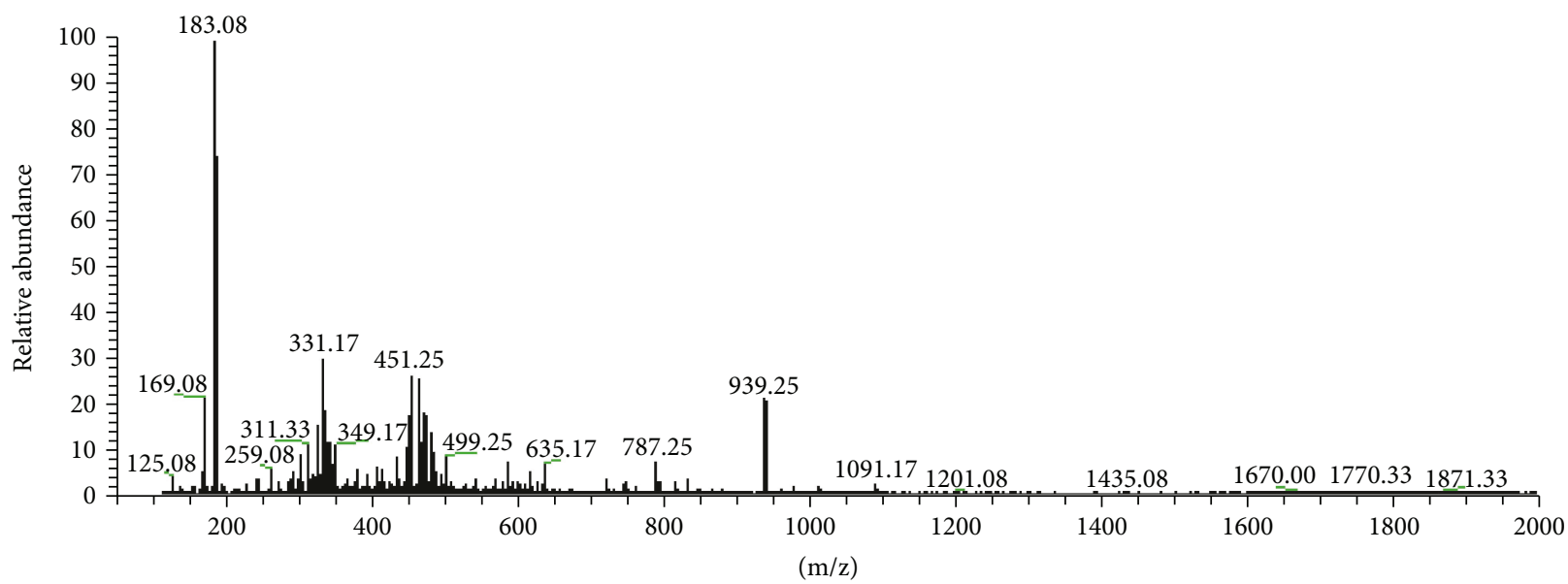

Full mass spectrum of $P$. nigrum

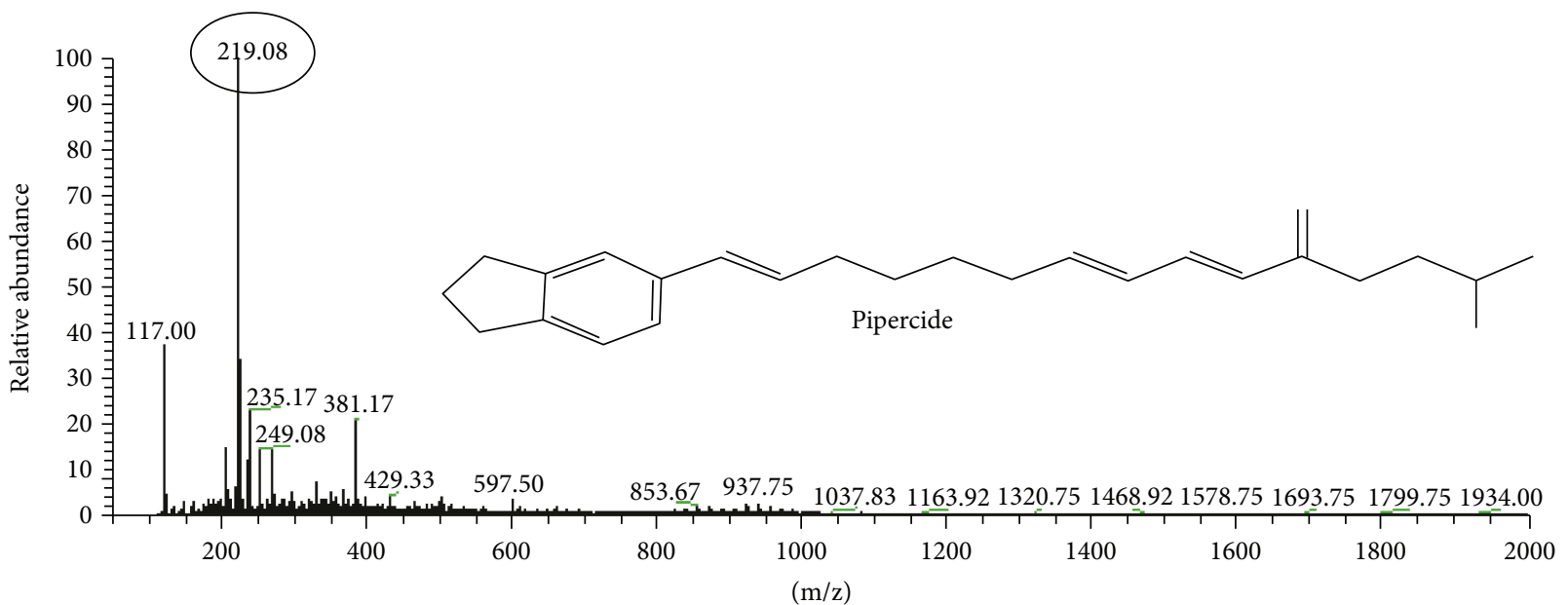

Mass spectrum of $P$. nigrum showing pipercide at $219.08 \mathrm{~m} / \mathrm{z}$

Figure 10: LC-MS analysis of P. nigrum.

positive control group. Among all the treatment groups, the group pretreated with $\mathrm{HC} 2$ and $\mathrm{HC} 4$ showed significant $(p>0.05)$ restoration of $\mathrm{HR}$.

3.12.2. Effect of Herbal Combinations on Ventricular Function. A significant decline in left ventricular end-diastolic pressure (LVEDP) $(9 \pm 3.05)$ marked the onset of myocardial infarction in surgically induced MI group which remained decreased throughout the experimental period in comparison to the normal control group $(32 \pm 5.51)$ (Figure 12). The pretreatment with HC4 and HC2 significantly $(p>0.05)$ maintained the LVEDP level as compared to the surgically induced ischemic group. The $\mathrm{HC} 1$ and $\mathrm{HC} 3$ also tried to sustain the LVEDP with corresponding values $12 \pm 4.04$ and $08 \pm 1.53$.

The positive control group showed the significant decrease in left ventricular systolic pressure (LVSP) as compared to the normal control group. The LADCA ligation resulted in significant cardiac dysfunction evidenced by reduced MAP and increased HR. The left ventricular contractile function was also altered. The pretreatment of HC4 showed the marked restoration as compared to other groups as it maintained the level of LVSP near to the normal control group. It is materialized that the $\mathrm{HC} 4$ is more potent in preventing the hemodynamic deteriorations observed in the positive control group.

3.13. Histopathological Examination. The histopathological findings of myocardial tissue in the normal control group illustrated clear integrity of the myocardial cell membrane. The myofibrillar structure was normal with no inflammatory cell infiltration. The nuclei were also normal without any pyknotic changes (Figure 13(a)). The histopathological examination of the surgically induced MI group showed extensive myofibrillar degeneration related to infiltration and disruption of cardiac myofibers. There was marked necrosis in the ventricular region. Pyknotic changes in nuclei were also observed (Figure 13(b)).

The treatment of $\mathrm{HC} 1$ prior to ligation showed myofibrilation (Figure 13(c)) while the pretreatment with $\mathrm{HC} 2$ demonstrated marked improvement in surgically induced alterations, but there was cellular infiltration at few places. The nuclei were also normal (Figure 13(d)). The group treated with HC3 did not protect the cardiac dysfunctions as compared to the other groups. Myocardial fibrillation as 


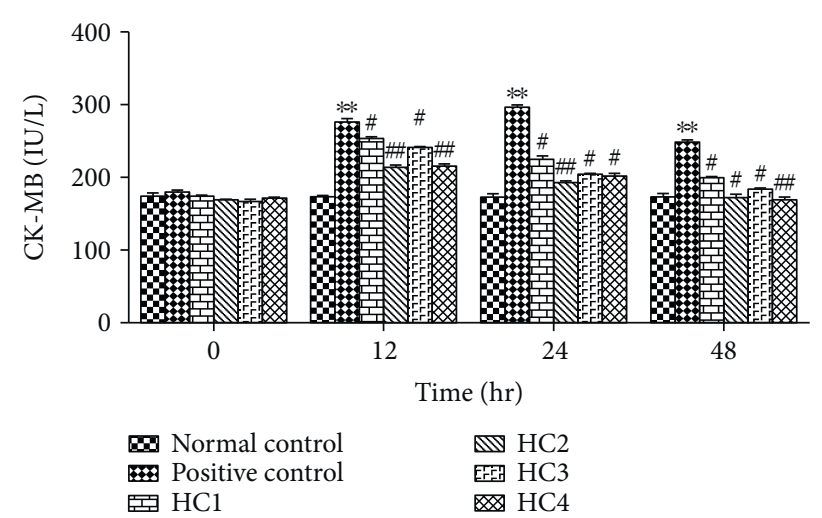

(a) Effect of herbal combinations of plant extracts on the level of

$$
\text { CK-MB (IU/L) }
$$

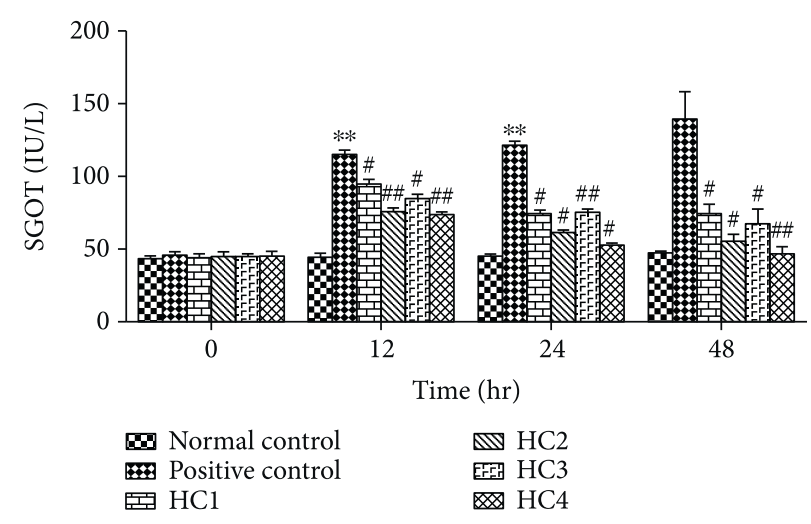

(b) Effect of herbal combinations of plant extracts on the level of SGOT (IU/L)

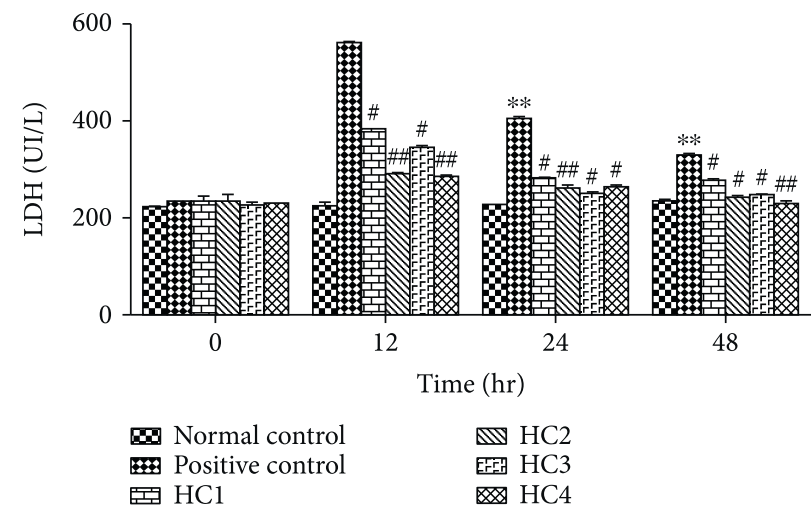

(c) Effect of herbal combinations of plant extracts on the level of

LDH (IU/L)

FIGURE 11: $(\mathrm{a}-\mathrm{c})$ Effect of herbal combinations of plant extracts on cardiac markers in the serum of all experimental groups. $* *$ indicates significance $(p<0.0001)$ compared to the normal control, \# indicates significance $(p<0.001)$ compared to the positive control, and \#\# indicates significance $(p<0.0001)$ compared to the positive control (ANOVA, Turkey's multiple comparison test). Values are presented as the mean $\pm \operatorname{SEM}(n=3)$.

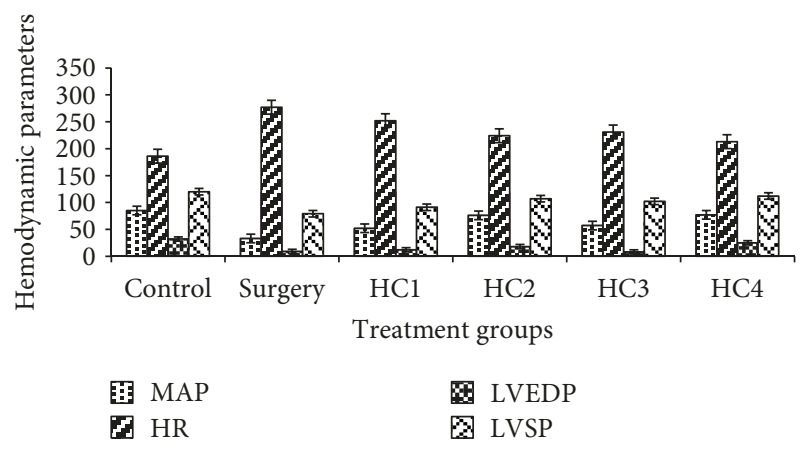

FIGURE 12: Hemodynamic parameters of various groups treated with different herbal combinations.

well as some pyknotic changes in the nuclei were also seen in the group treated with HC3 (Figure 13(e)). The histopathological examination of the group treated with HC4 showed that there was no myofibrilation, and the cardiac parenchyma was also normal. This confirmed the potential of herbal combination (HC4) over oxidative stress related to cardiac ailment (Figure 13(f)).

\section{Discussion}

The evidence-based study about metabolomes of medicinal plants is an emerging approach to develop a new group of phytotherapeutics [16]. The therapeutic potential of plant secondary metabolites has augmented an interest in pharmaceutical research for the development of novel therapeutic agents. The antioxidant profiling of the said medicinal plants was explored through DPPH and DNA protection assay. The antioxidative potential of these medicinal plants was found to be dose-dependent. This dose-dependent response of various medicinal plants for antioxidative potential has already been reported by many researchers $[18,25,26]$. The increased antioxidant potential with high dose of medicinal plants may be due to positive correlation with high quantity of powerful chain-breaking antioxidants like phenolics and other phytoconstituents [27]. Different mechanisms like scavenging of free radicals, chelation of metal ions, and inhibition of enzymes may be responsible for good therapeutic antioxidant potential of medicinal plants [28].

In HPLC, the extremely narrow peaks are generated; thus, the high-speed data handling performance demands a blend of MS segment [29]. LC-MS has such features that 


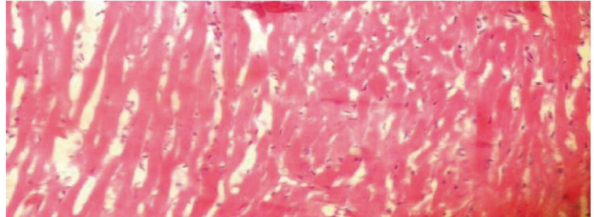

(a) Normal control group

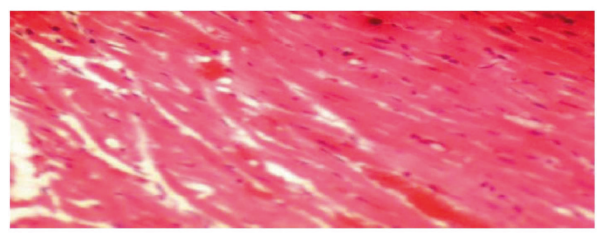

(c) HC1 group

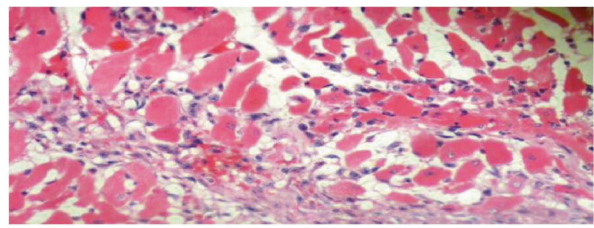

(e) HC3 group

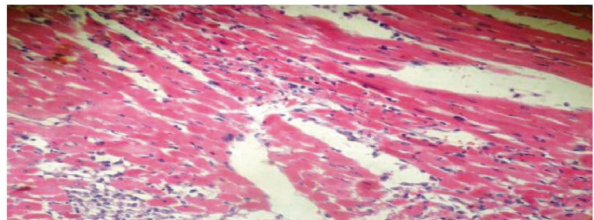

(b) Positive control group

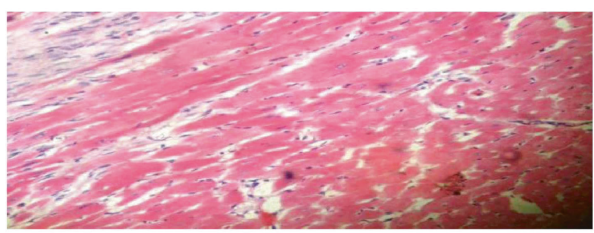

(d) HC2 group

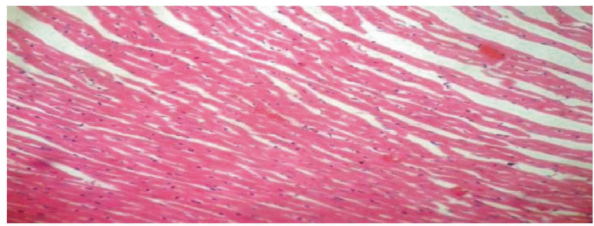

(f) HC4 group

FIgURE 13: (a-f) The histopathological representation of cardiac tissue of all treatment groups.

make it applicable for metabolomic profiling of a wide range of low to high polarity metabolites, including nonvolatile compounds. It also covers a broad range of metabolites, since it operates ionization in negative and positive modes [30]. Hence the LC-MS-based metabolomics is a powerful tool in order to evaluate the important active secondary metabolites which play a vital role to prevent oxidative stress by scavenging free radicals.

The LC-MS analysis of T. arjuna revealed the presence of some important phytoconstituents like termiarjunoside I, quercetin, ferulic acid, and gallic acid which were responsible for its antioxidative strength. The HPLC analysis of the T. arjuna bark by Jahan et al. [17] also exhibited the existence of polyphenols and phenolic acids including ferulic acid, gallic acid, caffeic acid, and catechin. The fast atom bombardment mass spectroscopy (FABMS) and distortionless enhancement by polarization transfer (DEPT) NMR spectra of $T$. arjuna also displayed a molecular ion peak at $\mathrm{m} / \mathrm{z}=666[\mathrm{M}]^{+}$indicating the presence of termiarjunoside $\mathrm{I}$, with a molecular formula of $\mathrm{C}_{36} \mathrm{H}_{58} \mathrm{O}_{11}$ (Ali et al. 2006). The quercetin and gallic acids are strong antioxidants which play a crucial role in a number of biological and pharmacological activities and also protect DNA damage [31]. The ferulic acid present in T. arjuna is not only a good antioxidant in various biological systems but also has the potential to protect the DNA against $\mathrm{H}_{2} \mathrm{O}_{2}$-induced damage [32].

The metabolomic profiling of C. oxyacantha depicted the presence of procynidine, crateagolic acid, ursolic acid, and quercetin. These major phytoconstituents are mainly responsible in curing various diseases like myocardial infarction, coronary heart diseases, hypertension, and diabetes-related complications owing to their antioxidant potential [33].
The presence of ursolic acid in C. oxyacantha has also been reported to have angiotensin-converting enzyme-inhibiting and cardioprotective potential (Lacaille et al. 2001). $R$. serpentina has been a popular field of research for decades, and several researchers have explored its excellent phytochemical properties $[34,35]$. Various secondary metabolites such as yohimbine, ajmaline, serpentine, and ajmalicine present in the roots of $R$. serpentina contribute for its antioxidant potential [36]. Ajmaline is a sodium channel blocker that illustrated the instant therapeutic potential when given intravenously. It has also been claimed to stimulate respiration and intestinal movements. Serpentine is useful to prevent the oxidative stress-induced DNA damage, hypertension, cardiovascular, and neurological diseases [37]. R. serpentina is a hopeful herbal option in the pharmaceutical world due to the existence of considerable bioactive compounds in the roots [38]. The LC-MS analysis of A. sativum indicated the existence of myricetin and apigenin. The myricetin due to its specific chemical structure counteracts oxidative stress generated as a result of reactive oxygen species $[39,40]$. The hydroxylated apigenin is found to inhibit tumor cell proliferation and angiogenesis. Caffeic acid is a potent antioxidant and has several therapeutic properties including antioxidants, anti-inflammatory, and anticarcinogenic. It has been reported that caffeic acid inhibits both lipoxygenase activity and suppresses lipid peroxidation thus completely blocks the production of ROS [41]. Cardamom fruit is used against vesicular calculi, dyspepsia, debility, halitosis, and gastrointestinal disorders [42]. Phytochemical investigation of cardamom has revealed highly bioactive components. High-phenolic compounds, in extracts of all plants, could be considered as the key reason behind the antioxidant potential of the said medicinal plants $[43,44]$. 
During in vivo trial, the increased cardiac markers in the positive control group are due to the ligation of the coronary artery. The ligation imparts an additional workload on the remaining viable myocytes that may be unbearable, resulting in pathological alterations [11]. Alterations in integrity, fluidity, and permeability of the myocardial membrane due to ligation have been believed to be a reason for the leakage of cardiac markers [21]. The treatment with HCs might salvage viable myocytes, which are at risk of injury, thus preventing cell loss induced by necrosis [45]. The HC4 showed the prominent cardioprotective potential by maintaining the cardio-specific markers near the normal against surgically induced myocardial infarction. The better maintenance of the cardiac markers with $\mathrm{HC} 4$ as compared to other herbal combinations might be due to the presence of synergism of some specific phytoconstituents like crateagolic acid, termiarjinoside-I, ajmaline, and serpentine and antioxidants like quercetin, gallic acid, ferulic acid, and myricetin in it. This may render the myocytes less leaky by preventing myocardial membrane destruction [46]. A considerable fall in MAP and increased HR in the surgically induced MI group indicated hemodynamic impairment and ventricular dysfunction due to increased generation of ROS [22]. A fall in MAP due to coronary occlusion is expected to increase HR and myocardial contractility by activating the baroreceptor reflex, which may subsequently result in reflex vasoconstriction and thus worsening the imbalance, between myocardial oxygen demand and supply [47]. The increase in blood flow through the subendocardial region of the left ventricular muscle is the major consequence of the reduction in LVEDP in the surgically induced infarction group [48]. The therapeutic efficacy of $\mathrm{HC} 4$ might be due to the improvement in both inotropic and lusitropic function of the heart and considerable maintenance of antioxidant defense capacity of the myocardium [48].

\section{Conclusion}

The HC4 (T. arjuna, R. serpentina, E. cardamom, and C. oxyacantha) considerably ameliorated cardiotoxicity by keeping the levels of biochemical parameters near to normal. The antioxidants property and phytoconstituents of medicinal plants present in this herbal combination might be responsible for its cardioprotective potential. On the basis of this evidence-based study, it can be concluded that the HC4 can be safely used as an alternative product for the management of cardiovascular diseases.

\section{Conflicts of Interest}

The authors declare that they have no conflicts of interest.

\section{Acknowledgments}

This work was supported by the Higher Education Commission, Pakistan, under the Indigenous 5000 PHD Fellowship Program pin no. 112-24406-2BM1-387.

\section{References}

[1] S. Kalita, G. Kumar, L. Karthik, and K. V. B. Rao, "In vitro antioxidant and DNA damage inhibition activity of aqueous extract of Lantana camara L. (Verbenaceae) leaves," Asian Pacific Journal of Tropical Biomedicine, vol. 2, no. 3, pp. S1675-S1679, 2012.

[2] M. Zahin, F. Aqil, and I. Ahmad, "The in vitro antioxidant activity and total phenolic content of four Indian medicinal plants," International Journal of Pharmacy and Pharmaceutical Sciences, vol. 1, pp. 88-95, 2009.

[3] M. Vishnupriya, S. Nishaa, J. M. Sasikumar, and V. K. Gopalakrishnan, "Antioxidant activity and hydroxyl radical induced DNA damage protection effect of aqueous extract of Curcuma amada," Research Journal of Pharmaceutical, Biological and Chemical Sciences, vol. 3, pp. 89-96, 2012.

[4] N. J. Ayesha, K. U. Rahman, and S. Nosheen, "Gemmomodification: an emerging source of natural antioxidants from Silybum marianum," Pakistan Journal of Pharmaceutical Sciences, vol. 26, pp. 585-591, 2013.

[5] G. Kumar, L. Karthik, and K. V. B. Rao, "Hemolytic activity of Indian medicinal plants towards human erythrocytes: an in vitro study," Elixir Applied Botany, vol. 40, pp. 55345537, 2011.

[6] M. Dianat, M. Radan, M. Badavi, and A. Sarkaki, "The evaluation of inotropic properties and antidysrhythmic effect of vanillic acid and exercise on $\mathrm{CaCl}_{2}$ induced arrhythmia in young and aged rats," Research Journal of Pharmaceutical, Biological and Chemical Sciences, vol. 5, p. 1545, 2014.

[7] G. Khan, S. E. Haque, T. Anwer, M. N. Ahsan, M. M. Safhi, and M. F. Alam, "Cardioprotective effect of green tea extract on doxorubicin induced cardiotoxicity in rats," Acta Poloniae Pharmaceutica. Drug Research, vol. 5, pp. 861-868, 2014.

[8] M. Shreya, A. Patra, A. Samanta et al., "Analysis of phytochemical profile of Terminalia arjuna bark extract with antioxidative and antimicrobial properties," Asian Pacific Journal of Tropical Biomedicine, vol. 3, no. 12, pp. 960-966, 2013.

[9] K. Vasu, J. V. Goud, A. Suryam, and M. A. S. Chary, "Biomolecular and phytochemical analyses of three aquatic angiosperms," African Journal of Microbiology Research, vol. 3, pp. 418-421, 2009.

[10] J. John, "Therapeutic potential of Withania somnifera: a report on phyto-pharmacological properties," International Journal of Pharmaceutical Sciences and Research, vol. 5, pp. 21312148, 2014.

[11] A. G. Beaulah, M. Sadiq, V. Sivakumar, and J. Santhi, "Cardioprotective activity of methanolic extract of Croton sparciflorus on isoproterenol induced myocardial infarcted Wistar albino rats," Journal of Medicinal Plants Studies, vol. 2, pp. 01-08, 2014.

[12] R. Susila, J. Gladys, R. Balagurusamy, and K. Mubarak, "A review of Siddha cardiology and cardioprotective herbs," Internation Journal of Herbal Medicine, vol. 1, pp. 71-75, 2013.

[13] S. Ittagi, V. K. Merugumolu, and R. S. Siddamsetty, "Cardioprotective effect of hydroalcoholic extract of Tecoma stans flowers against isoproterenol induced myocardial infarction in rats," Asian Pacific Journal of Tropical Disease, vol. 4, pp. 378-384, 2014.

[14] P. K. Mukherjee, R. K. Harwansh, S. Bahadur et al., "Metabolomics of medicinal plants - a versatile tool for standardization of herbal products and quality evaluation of ayurvedic formulations," Current Science, vol. 111, pp. 1624-1630, 2016. 
[15] M. N. Alamgeer, H. Malik, S. Bashir et al., "Cardiotonic and vasoconstriction effects of aqueous methanolic extract of Paspalidium flavidum L," Pakistan Journal of Pharmaceutical Sciences, vol. 28, pp. 437-441, 2015.

[16] L. F. Shyur and N. S. Yang, "Metabolomics for phytomedicine research and drug development," Current Opinion in Chemical Biology, vol. 12, no. 1, pp. 66-71, 2008.

[17] N. Jahan, K. U. Rehman, and S. Ali, "Cardioprotective and antilipidemic potential of Cyprus rotundus in chemically induced cardiotoxicity," International Journal of Agriculture and Biology, vol. 14, pp. 989-992, 2012.

[18] A. Yadav, R. Bhardwaj, and R. A. Sharma, "Free radical scavenging potential of the Solanum surattense Burm f.: an important medicinal plant," International Journal of Pharmacy and Pharmaceutical Science, vol. 6, pp. 39-42, 2014.

[19] M. Riaz, N. Rasool, I. H. Bukhari et al., "In vitro antimicrobial, antioxidant, cytotoxicity and GC-MS analysis of Mazus goodenifolius," Molecules, vol. 17, pp. 14275-14287, 2012.

[20] Y. Jiao and Y. Zuo, "Ultrasonic extraction and HPLC determination of anthraquinones, aloe-emodine, emodine, rheine, chrysophanol and physcione, in roots of Polygoni multiflori," Phytochemical Analysis, vol. 20, pp. 272-278, 2009.

[21] S. Ojha, M. Nandave, S. Kumari, and D. S. Arya, "Cardioprotection by Inula racemosa Hook in experimental model of myocardial ischemic reperfusion injury," Indian Journal of Experimental Biology, vol. 48, pp. 918-924, 2010.

[22] S. K. Ojha, S. Bharti, S. Joshi, S. Kumari, and D. S. Arya, "Protective effect of hydroalcoholic extract of Andrographis paniculata on ischaemia reperfusion induced myocardial injury in rats," Indian Journal of Medical Research, vol. 135, pp. 414-421, 2012.

[23] M. Nandave, S. K. Ojha, S. Kumari et al., "Cardioprotective effect of root extract of Picrorhiza kurroa (Royle Ex Benth) against isoproterenol-induced cardiotoxicity in rats," Indian Journal of Experimental Biology, vol. 51, pp. 694-701, 2013.

[24] E. Berman and X. Wang, Exercising Essential Statistics, CQ press, USA, 2017.

[25] S. K. Shukla, A. Kumar, M. Terrence, J. Yusuf, V. P. Singh, and M. Mishra, "The probable medicinal usage of Cassia tora: an overview," Online Journal of Biological Science, vol. 13, pp. 13-17, 2013.

[26] A. Soni and S. Sosa, "Phytochemical analysis and free radical scavenging potential of herbal and medicinal plant extracts," Journal of Pharmacognosy and Phytochemistry, vol. 2, pp. 22-29, 2013.

[27] R. K. Sahu, M. Kar, and R. Routray, "DPPH free radical scavenging activity of some leafy vegetables used by tribals of Odisha," Indian Journal of Medicinal Plants Studies, vol. 1, pp. 21-27, 2013.

[28] K. Soumia, D. Tahar, L. Lynda, B. Saida, C. Chabane, and M. Hafidha, "Antioxidant and antimicrobial activities of selected medicinal plants from Algeria," Journal of Coastal Life Medicine, vol. 2, pp. 478-483, 2014.

[29] T. Ogura and Y. Sakamoto, Application of Metabolomics Techniques Using LC/MS and GC/MS Profiling Analysis of Green Tea Leaves, SHIMADZU Corporation, 2012.

[30] S. R. Mallick, R. C. Jena, and K. C. Samal, "Rapid in vitro multiplication of an endangered medicinal plant sarpgandha (Rauvolfia serpentina)," American Journal of Plant Sciences, vol. 3, pp. 437-442, 2012.
[31] G. Nikolic, A. Veselinovic, Z. Mitic, and S. Zivanovic, "HPLCDAD study of gallic acid autoxidation in alkaline aqueous solutions and the influence of $\mathrm{Mg}(\mathrm{II})$ ion," Scientific Journal of the Faculty of Medicine, vol. 28, pp. 219-224, 2011.

[32] B. D. Paiva, R. Goldbeck, W. D. D. Santos, and F. M. Squina, "Ferulic acid and derivatives: molecules with potential application in the pharmaceutical field," Brazilian Journal of Pharmaceutical Sciences, vol. 3, pp. 395-411, 2013.

[33] C. P. Kashyap, V. Arya, and N. Thakur, "Ethnomedicinal and phytopharmacological potential of Crataegus oxyacantha Linn. - a review," Asian Pacific Journal of Tropical Biomedicine, vol. 2, pp. 1194-1199, 2012.

[34] B. Mittal, A. Meenakshi, A. Sharma, and V. K. Gothecha, "Phytochemical and pharmacological activity of Rauwolfia serpentina - a review," International Journal of Ayurvedic And Herbal Medicine, vol. 2, pp. 427-434, 2012.

[35] S. A. Poonam and S. Mishra, "Physiological, biochemical and modern biotechnological approach to improvement of Rauwolfia serpentina," Journal of Pharmacy and Biological Science, vol. 6, pp. 73-78, 2013.

[36] A. Morales, "Yohimbine in erectile dysfunction: the facts," International Journal of Impotence Research, vol. 12, pp. S70S74, 2000.

[37] B. V. Gawade and S. A. Fegade, "Rouwolfia (reserpine) as a potential antihypertensive agent: a review," International Journal of Pharmaceutical and Phytopharmacological Research, vol. 2, pp. 46-49, 2012.

[38] S. Rolf, H. J. Bruns, T. Wichter et al., "The ajmaline challenge in Brugada syndrome: diagnostic impact, safety, and recommended protocol," European Heart Journal, vol. 24, pp. 1104-1112, 2003.

[39] C. T. Mary, R. Kingston, D. Gilroy, M. Lehane, and A. Furey, "Hawthorn (Crataegus spp.) in the treatment of cardiovascular disease," Pharmacognosy Reviews, vol. 4, pp. 32-41, 2010.

[40] A. J. Larson, J. D. Symons, and T. Jalili, “Therapeutic potential of quercetin to decrease blood pressure: review of efficacy and mechanisms," Advances in Nutrition: An International Review Journal, vol. 3, pp. 39-46, 2012.

[41] R. Jayanthi and P. Subash, "Antioxidant effect of caffeic acid on oxytetracycline induced lipid peroxidation in albino rats," Indian Journal of Clinical Biochemistry, vol. 25, pp. 371-375, 2010.

[42] S. S. Husain and M. Ali, "Analysis of volatile oil of the fruits of Elettaria cardamomum (L.) Maton and its antimicrobial activity," World Journal of Pharmacy and Pharmaceutical Sciences, vol. 3, pp. 1798-1808, 2014.

[43] U. Golla and S. S. R. Bhimathati, "Evaluation of antioxidant and DNA damage protection activity of the hydroalcoholic extract of Desmostachya bipinnata L. Stapf," The Scientific World Journal, vol. 2014, Article ID 215084, 8 pages, 2014.

[44] E. K. F. Savan and Z. Kuçukbay, "Essential oil composition of Elettaria cardamom Maton," Journal of Applied Biological Sciences, vol. 5, pp. 78-79, 2013.

[45] I. R. Mohanty, S. K. Gupta, N. Mohanty, D. Joseph, and Y. Deshmukh, "The beneficial effects of herbs in cardiovascular diseases," Global Journal of Medical research, vol. 12, pp. 38-58, 2012.

[46] S. Aslam, N. Jahan, and K. M. Khan, "Efficacy of herbal mixture for the treatment of salbutamol induced myocardial necrosis in rabbits," Pakistan Veterinary Journal, vol. 35, no. 3, pp. 355-359, 2015. 
[47] S. K. Gupta, I. Mohanty, K. K. Talwar, A. Dinda, S. Joshi, and P. Bansal, "Cardioprotection from ischemia and reperfusion injury by Withania somnifera: a hemodynamic, biochemical and histopathological assessment," Molecular and Cellular Biochemistry, vol. 260, pp. 39-47, 2004.

[48] I. R. Mohanty, D. S. Arya, and S. K. Gupta, "Dietary Curcuma longa protects myocardium against isoproterenol induced hemodynamic, biochemical and histopathological alternations in rats," International Journal of Applied Research in Natural Products, vol. 1, pp. 19-28, 2009. 


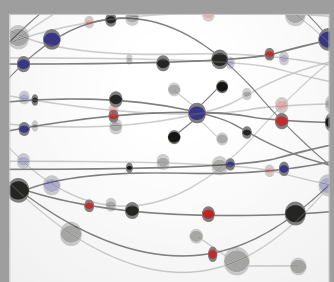

The Scientific World Journal
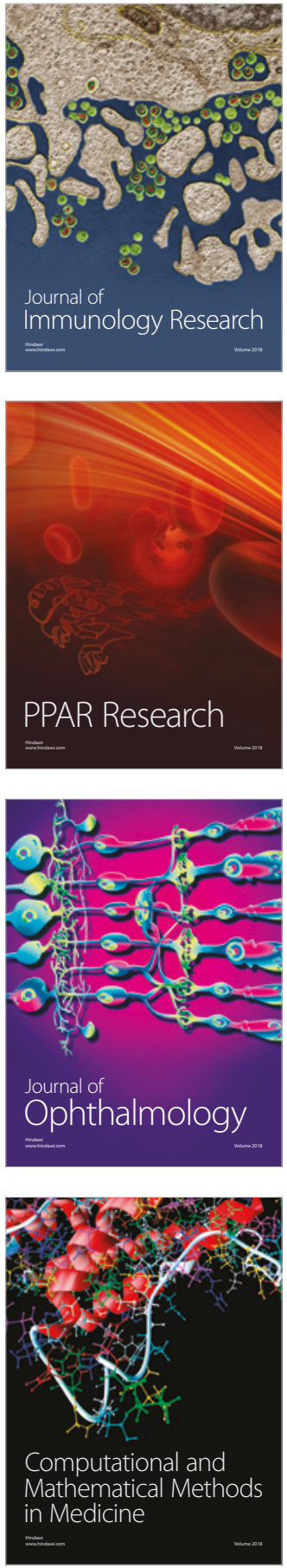

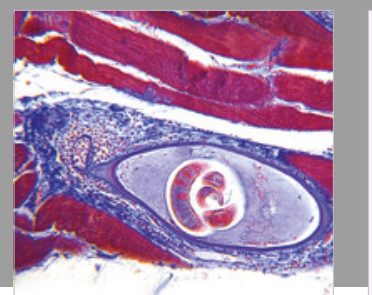

Gastroenterology Research and Practice

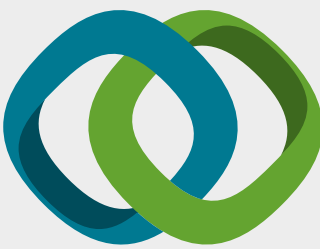

\section{Hindawi}

Submit your manuscripts at

www.hindawi.com
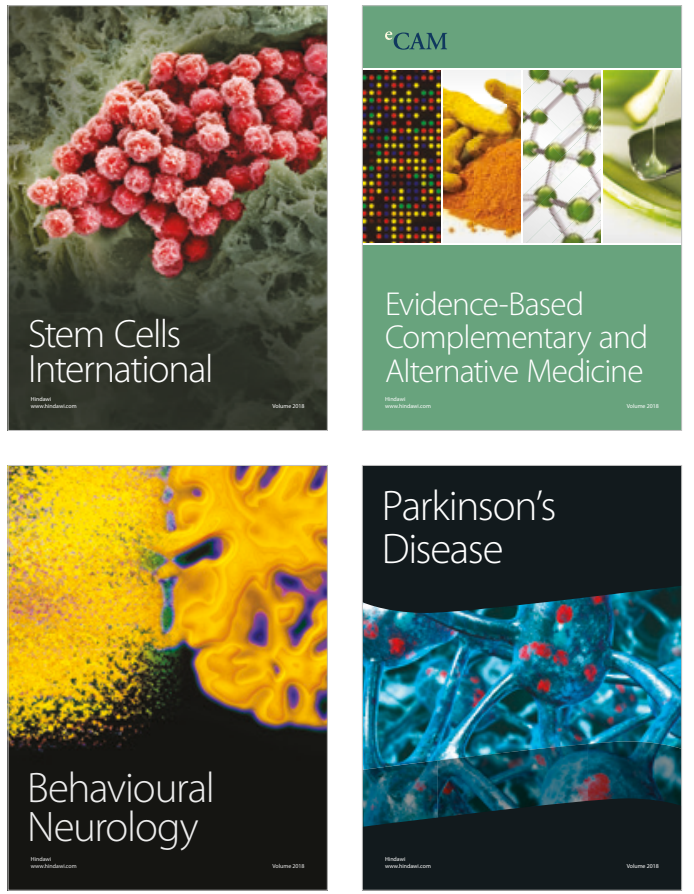

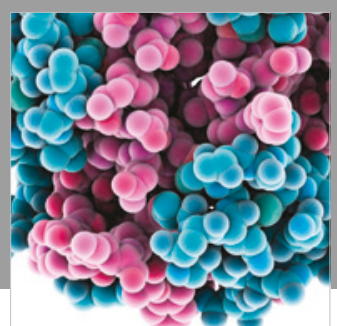

ournal of

Diabetes Research

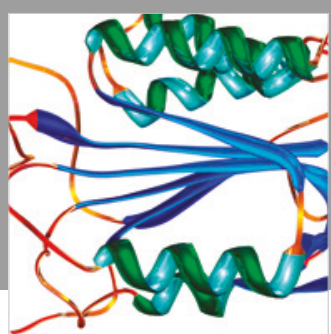

Disease Markers
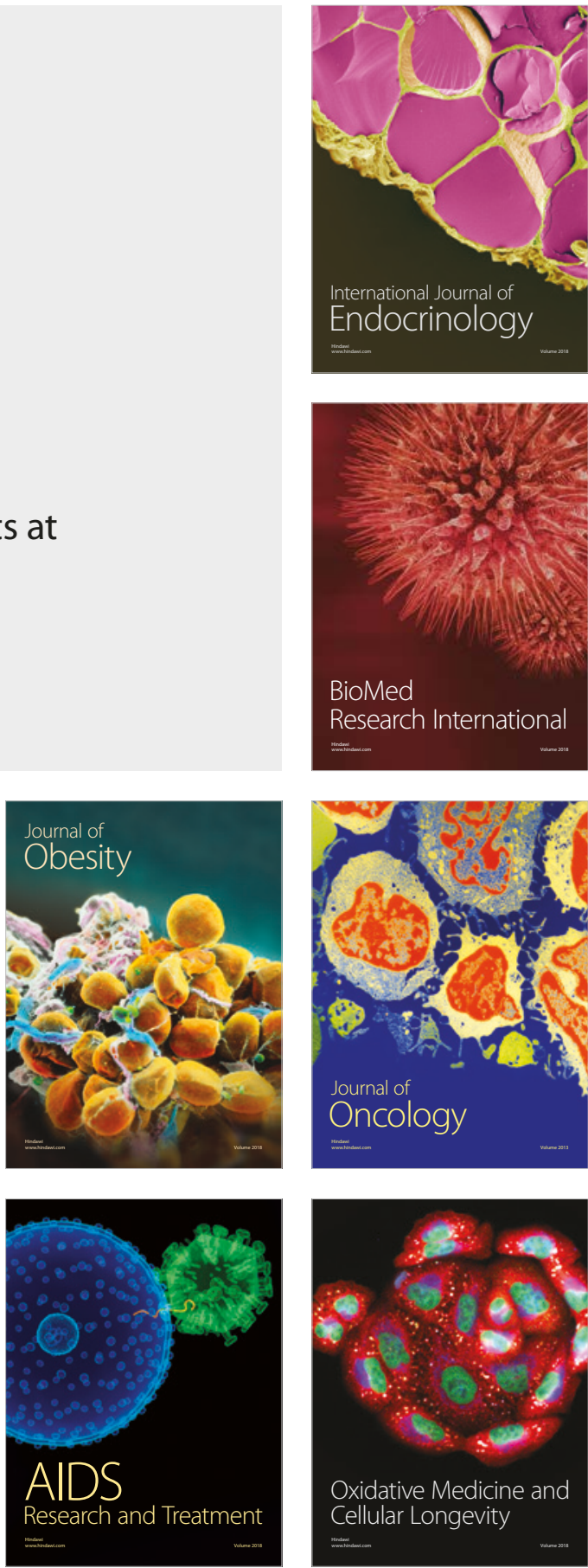